\title{
Enhanced Plasmon-Induced Resonance Energy Transfer (PIRET)-mediated Photothermal and Photodynamic Therapy Guided by Photoacoustic and Magnetic Resonance Imaging
}

Zheng, Tao; Zhou, Tongchang; Feng, Xiaotong; Shen, Jian ; Zhang, Ming; Sun, Yi

\section{Published in:}

A C S Applied Materials and Interfaces

Link to article, DOI:

10.1021/acsami.9b09296

Publication date:

2019

Document Version

Peer reviewed version

Link back to DTU Orbit

Citation (APA):

Zheng, T., Zhou, T., Feng, X., Shen, J., Zhang, M., \& Sun, Y. (2019). Enhanced Plasmon-Induced Resonance Energy Transfer (PIRET)-mediated Photothermal and Photodynamic Therapy Guided by Photoacoustic and Magnetic Resonance Imaging. A C S Applied Materials and Interfaces, 11(35), 31615-31626.

https://doi.org/10.1021/acsami.9b09296

\section{General rights}

Copyright and moral rights for the publications made accessible in the public portal are retained by the authors and/or other copyright owners and it is a condition of accessing publications that users recognise and abide by the legal requirements associated with these rights.

- Users may download and print one copy of any publication from the public portal for the purpose of private study or research.

- You may not further distribute the material or use it for any profit-making activity or commercial gain

- You may freely distribute the URL identifying the publication in the public portal 


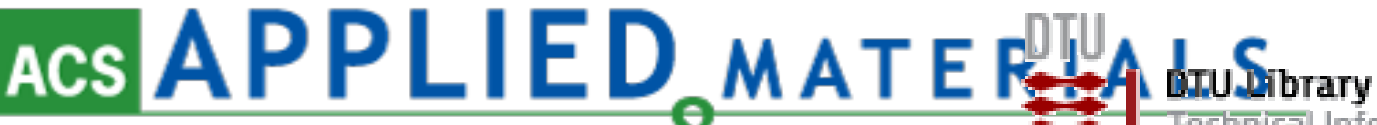 \\ INTERFA CES Initromation Centere of Denmarle}

Subscriber access provided by DTU Library

\section{Biological and Medical Applications of Materials and Interfaces}

\section{Enhanced Plasmon-Induced Resonance Energy Transfer (PIRET)-mediated Photothermal and Photodynamic Therapy Guided by Photoacoustic and Magnetic Resonance Imaging}

Tao Zheng, Tongchang Zhou, Xiaotong Feng, Jian Shen, Ming Zhang, and Yi Sun

ACS Appl. Mater. Interfaces, Just Accepted Manuscript • DOI: 10.1021/acsami.9b09296 • Publication Date (Web): 30 Jul 2019

Downloaded from pubs.acs.org on August 1, 2019

\section{Just Accepted}

"Just Accepted" manuscripts have been peer-reviewed and accepted for publication. They are posted online prior to technical editing, formatting for publication and author proofing. The American Chemical Society provides "Just Accepted" as a service to the research community to expedite the dissemination of scientific material as soon as possible after acceptance. "Just Accepted" manuscripts appear in full in PDF format accompanied by an HTML abstract. "Just Accepted" manuscripts have been fully peer reviewed, but should not be considered the official version of record. They are citable by the Digital Object Identifier (DOI®). "Just Accepted" is an optional service offered to authors. Therefore, the "Just Accepted" Web site may not include all articles that will be published in the journal. After a manuscript is technically edited and formatted, it will be removed from the "Just Accepted" Web site and published as an ASAP article. Note that technical editing may introduce minor changes to the manuscript text and/or graphics which could affect content, and all legal disclaimers and ethical guidelines that apply to the journal pertain. ACS cannot be held responsible for errors or consequences arising from the use of information contained in these "Just Accepted" manuscripts. 


\begin{abstract}
Phototherapy, containing photothermal and photodynamic therapy, has attracted extensive attention due to its noninvasive nature, low toxicity, and high anticancer efficiency. Charge-separation mechanism of plasmon-induced resonance energy transfer (PIRET), has been increasingly employed to design nanotheranotic agents. Herein, we developed a novel and smart PIRET-mediated nanoplatform for enhanced, imaging-guided phototherapy. Prussian blue (PB) was incorporated into $\mathrm{Au} @ \mathrm{Cu}_{2} \mathrm{O}$ nanostructure, which was then assembled with poly(allylamine) (PAH) modified black phosphorus quantum dots (Au@PB@ $\mathrm{Cu}_{2} \mathrm{O} @ \mathrm{BPQDs} / \mathrm{PAH}$ nanocomposites). The hybrid nanosystem exhibited great absorption in NIR region, as well as the ability to self-supply $\mathrm{O}_{2}$ by catalyzing hydrogen peroxide and convert $\mathrm{O}_{2}$ into singlet oxygen $\left({ }^{1} \mathrm{O}_{2}\right)$ under $650 \mathrm{~nm}$ laser light $\left(0.5 \mathrm{~W} / \mathrm{cm}^{2}\right)$ irradiation. In vitro and in vivo assay showed that the generated heat and toxic ${ }^{1} \mathrm{O}_{2}$ from $\mathrm{Au} @ \mathrm{~PB} @ \mathrm{Cu}_{2} \mathrm{O} @ \mathrm{BPQDs} / \mathrm{PAH}$ nanocomposites could effectively kill the cancer cells and suppress tumor growth. Moreover, the unique properties of PB modified nanosystem allowed for synergistic therapy with the aid of $T_{1}$-weighed magnetic resonance imaging $\left(T_{1}\right.$-weighted $\left.\mathrm{MRI}\right)$ and photoacoustic imaging $(\mathrm{PAI})$. This study presented a suitable way to fabricate smart PIRET-based nanosystem with enhanced PTT/PDT efficacy and dual-modal imaging functionality. The great biocompatibility and low toxicity ensured their high potential for use in cancer therapy.
\end{abstract}

KEYWORDS: phototherapy, plasmon-induced resonance energy transfer, prussian blue, magnetic resonance imaging, photoacoustic imaging, biocompatibility 


\section{Introduction}

In the past few years, phototherapy such as photothermal therapy (PTT) and photodynamic therapy (PDT) has attracted extensively attention in cancer treatment due to the advantages of specific tumor localization, remote control, and low system toxicity. ${ }^{1-4}$ PTT uses near-Infrared light (NIR) absorbing agents to produce heat from optical energy, leading to the ablation of tumor. ${ }^{5,6}$ Recently, many photothermal agents, such as gold nanoparticles (NPs), ${ }^{7}$ copper sulfide $\mathrm{NPs},{ }^{8}$ black phosphorus nanosheets, ${ }^{9} \mathrm{MoS}_{2}$ nanaosheets, ${ }^{10}$ boron nanosheets, ${ }^{11}$ have been extensively explored. For PDT, the treatment is based on the photosensitizer (PBs) triggered by specific NIR light, then producing reactive oxygen species (ROS) to kill the cancer cells. ${ }^{12,13}$ In general, the traditional organic PBs show poor water solubility, low stability and quantum yield, which limits their further application in PDT. ${ }^{14}$ Recently, the semiconductor NPs including $\mathrm{TiO}_{2},{ }^{15}$ $\mathrm{ZnO},{ }^{16} \mathrm{Cu}_{2} \mathrm{O},{ }^{17}$ provide a new thought to design PBs. Nevertheless, some of these inorganic PBs can only be activated by narrow UV-vis light, which has a prominent limitation in tissue penetration.

According to the aforementioned limitation of PDT, localized surface plasmon resonance (LSPR) has emerged as a new strategy to fabricate efficient PBs with great NIR absorption by incorporating plasmonic metal nanostructures (e.g. $\mathrm{Au}, \mathrm{Ag}$ and $\mathrm{Cu}$ ) in semiconductor for enhanced PDT.18,19 Recently, Wu's group fabricated the $\mathrm{Au} @ \mathrm{SiO}_{2} @ \mathrm{Cu}_{2} \mathrm{O}$ nanosystem, which showed much higher photocatalytic activity than both $\mathrm{Cu}_{2} \mathrm{O}$ and $\mathrm{Au} @ \mathrm{Cu}_{2} \mathrm{O} \cdot{ }^{17}$ Introducing gold NPs into $\mathrm{Cu}_{2} \mathrm{O}$ can expand the light absorption and improve its depth of penetration into tissues. Most importantly, according to the unique charge-separation mechanism of PIRET, the $\mathrm{SiO}_{2}$ layer in $\mathrm{Au} @ \mathrm{SiO}_{2} @ \mathrm{Cu}_{2} \mathrm{O}$ nanosystem can serve as a separating layer and prominently enhances the generation of electron-hole pairs in the $\mathrm{Cu}_{2} \mathrm{O}$ shell, and consequently improve the generation of ${ }^{1} \mathrm{O}_{2}$ for enhanced PDT. ${ }^{20-22}$ Similar to $\mathrm{Au} @ \mathrm{SiO}_{2} @ \mathrm{Cu}_{2} \mathrm{O}$ nanosystem, a gold-copper sulfide yolkshell ( $\mathrm{Au} @ \mathrm{CuS})$ nanoparticle has been synthesized. It enhanced PDT performance using PIRET effects. ${ }^{23}$ Therefore, the PIRET charge-separation mechanism based nanostructures seem to be promising phototherapy agents.

Although integrating $\mathrm{Cu}_{2} \mathrm{O}$ nanomaterials with plasmonic noble metal nanomaterials improved PDT, the use of such hybrid nanomaterials for cancer treatment is greatly limited by the hypoxia microenvironment, because the essential element of oxygen is insufficient in tumor. Another disadvantage of these nanosystems was that the photothermal property was lacking. ${ }^{17,24}$ In addition, 
it remains a great challenge to develop multi-functional nanomaterials that can simultaneously provide multi-modality imaging and efficient PIRET-mediated PTT and PDT for tumor treatment.

Prussian Blue (PB) with excellent biocompatibility has been approved by American Food and Drug Administration (FDA) for clinical application. ${ }^{25-27}$ In addition to its excellent photothermal performance, it can be further used as strong contrast agent for both photoacoustic imaging (PAI) and magnetic resonance imaging (MRI) in early cancer diagnosing. ${ }^{28-30}$ Moreover, Prussian blue NPs possess a catalysis-like activity that can catalyze hydrogen peroxide, which is promising to overcome the problems of hypoxia tumor microenvironment that limits PDT efficacy. ${ }^{31}$ In addition, Black phosphorus quantum dots (BPQDs), as a new form of black phosphorus nanostructures, has emerged as functional nanomaterials in 2015. ${ }^{32,33}$ The nanostructures of BPQDs are obviously different from two-dimensional (2D) BP nanosheets and one-dimensional (1D) BP nanoribbons. BPQDs can enhance photodynamic performance by generating ${ }^{1} \mathrm{O}_{2}$ in tumor microenvironment under $650 \mathrm{~nm}$ laser light. ${ }^{34-36}$ Importantly, BPQDs might be effectively discharged from the liver and kidneys because its particle size is smaller than $10 \mathrm{~nm} \cdot{ }^{37}$

Inspired by the above research results, we have successfully built a PIRET based, multimodal imaging-guided PTT and PDT nanosystem (Au@PB@ $\mathrm{Cu}_{2} \mathrm{O} @$ BPQDs/PAH nanocomposites) in this study. Firstly, gold nanorods were synthesized, and then a PB layer with the thickness of $10 \pm$ $2 \mathrm{~nm}$ was coated onto the surface of gold nanorods ( $\mathrm{Au} \mathrm{NRs}$ ). Next, $\mathrm{Cu}_{2} \mathrm{O}$ shell was grafted on PB. Finally, PAH modified BPQDs were coupled on $\mathrm{Cu}_{2} \mathrm{O}$ via electrostatic interaction. Here, $\mathrm{PAH}$ served as modified layer to increase water stability and biocompatibility of $\mathrm{Au} @ \mathrm{~PB} @ \mathrm{Cu}_{2} \mathrm{O} @ \mathrm{BPQDs} / \mathrm{PAH}$ nanocomposites (Au@PB@ $\left.\mathrm{Cu}_{2} \mathrm{O} @ \mathrm{BPQDs} / \mathrm{PAH} \mathrm{NCs}\right)$, as well as the prevention the oxidation of BPQDs. By taking advantage of the PIRET process, the $\mathrm{Au} @ \mathrm{~PB} @ \mathrm{Cu}_{2} \mathrm{O}$ NPs showed high generation of ${ }^{1} \mathrm{O}_{2}$ than $\mathrm{Au} @ \mathrm{Cu}_{2} \mathrm{O}$ NPs under 650 nm laser light $\left(0.5 \mathrm{~W} / \mathrm{cm}^{2}\right)$, and verified great production of ${ }^{1} \mathrm{O}_{2}$ after combining with $\mathrm{PAH}$ modified BPQDs. Importantly, $\mathrm{Au} @ \mathrm{~PB} @ \mathrm{Cu}_{2} \mathrm{O} @ \mathrm{BPQDs} / \mathrm{PAH} \mathrm{NCs}$ displayed an excellent PTT performance at $650 \mathrm{~nm}$ laser light $\left(1.5 \mathrm{~W} / \mathrm{cm}^{2}\right)$ due to the presence of $\mathrm{PB}$, while the property was lacking in other PIRET-mediated $\mathrm{Cu}_{2} \mathrm{O}$ core-shell nanostructures. Moreover, the $\mathrm{PB}$ endowed the sample with simultaneous PA and $T_{1}$-weighted MR imaging properties. As a result, an enhanced PIRET-mediated phototherapy has been fabricated, which exhibited synergetic PAI, MRI-guided PTT/PDT efficacy in the treatment of cancer therapy. 


\section{Experimental section}

Chemicals. All of the aforementioned chemicals were used in this article without further purification. All agents were obtained from Sigma-Aldrich except bulk BP and potassium ferrocyanide trihydrate, which were purchased from Smart Elements and Thermo Fisher. All procedures for animal experiments were handled under the guidelines approved and supervised by the ethics committee of Nanjing University.

Apparatus. The infrared spectrum was performed on a (FT-IR) Nexus 670 FTIR type (Nicolet). UV-Vis spectra were recorded using a Shimadzu UV-2600 spectrometer. The surface composition and element analysis of the samples were recorded using X-ray photoelectron spectroscopy (XPS, EscaLab-250, Thermo, USA). Transmission electron microscopy (TEM), high-resolution TEM (HRTEM), and energy-dispersive spectroscopy spectrum (EDS) analyses of samples were carried out on a Tecnai G20 operating. Raman spectrometer (LabRam HR800) with $514 \mathrm{~nm}$ laser excitation was used to measure the Raman spectra of BPQDs. ESR spectrum of sample was measured by using Bruker EMXplus Spectrometer System. $\zeta$ potential was conducted using Malvern DLS Zetasizer. The fluorescent images of cells were acquired by Confocal laser scanning microscopy (CLSM, TI-E-AIR, Nikon, Japan). The obtained infrared thermal images at tumor site exposuring to 650 laser light irradiation were recorded with a PTT monitoring system MG33 (Shanghai Magnity Electronics Co. Ltd.). The process of synthesizing material are shown in the Supporting Information.

\section{Results and discussion}

Synthesis and Characterization. In this study, multifunctional $\mathrm{Au} @ \mathrm{~PB} @ \mathrm{Cu}_{2} \mathrm{O} @ \mathrm{BPQDs} / \mathrm{PAH}$ NCs were fabricated and its multimodal-imaging guided therapeutic effect was shown in scheme 1, The NC contains two main composites: $\mathrm{Au} @ \mathrm{~PB} @ \mathrm{Cu}_{2} \mathrm{O}$ NPs and BPQDs/PAH NPs, respectively. In $\mathrm{Au} @ \mathrm{~PB} @ \mathrm{Cu}_{2} \mathrm{O}$ nanosystem, PB modified gold nanorods can equip Au@Cu $\mathrm{Cu}_{2} \mathrm{O}$ NPs with PTT effect, while the traditional $\mathrm{Au} @ \mathrm{Cu}_{2} \mathrm{O}$ NPs were unable to exhibit the property due to their relative low absorption throughout the NIR region. ${ }^{38}$ In addition, we utilized $\mathrm{PB}$ to separate gold nanorod and $\mathrm{Cu}_{2} \mathrm{O}$ to take full advantage of plasmonic gold nanorods and consequently improved the photocatalytic activity on the surface of $\mathrm{Cu}_{2} \mathrm{O}$, generating more ${ }^{1} \mathrm{O}_{2}$ to kill the cancer cells. Furthermore, It has been verified that Prussian Blue displays a catalase-like activity to catalyze hydrogen peroxide $\left(\mathrm{H}_{2} \mathrm{O}_{2}\right)$ into oxygen $\left(\mathrm{O}_{2}\right)$ molecules 
under the neutral $\mathrm{pH}$ condition $(\mathrm{pH}=7.4) .{ }^{31}$ Due to the excellent absorption through the NIR region of PB, PB modified $\mathrm{Au} @ \mathrm{Cu}_{2} \mathrm{O}$ nanostructures can also be used as photo-absorbing agent for PAI and $T_{1}$-MRI because of its Fe(II) and Fe(III) constituent. On the other hand, combining Au@PB@ $\mathrm{Cu}_{2} \mathrm{O}$ NPs with BPQDs/PAH NPs for further enhanced PDT, which has been demonstrated by zeta potential results (Figure S1). Thus, through integration of these two main composites, the Au@PB@ $\mathrm{Cu}_{2} \mathrm{O} @ \mathrm{BPQDs} / \mathrm{PAH} \mathrm{NCs}$ could be excited at the $650 \mathrm{~nm}$ laser light for PAI and $T_{1}$-MRI guided PTT/PDT.

(a)

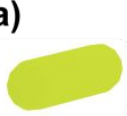

Au NRs
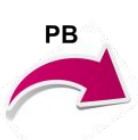

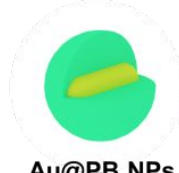

Au@PB NPs
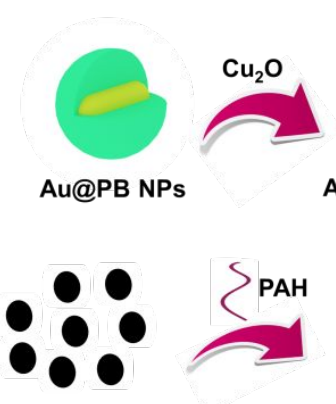

BPQDs

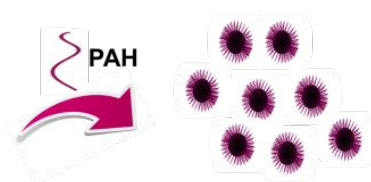

BPQDs/PAH NPs
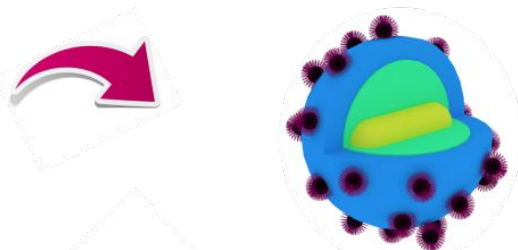

Au@PB@Cu $u_{2} O @ B P Q D s / P A H ~ N C s$

(b)

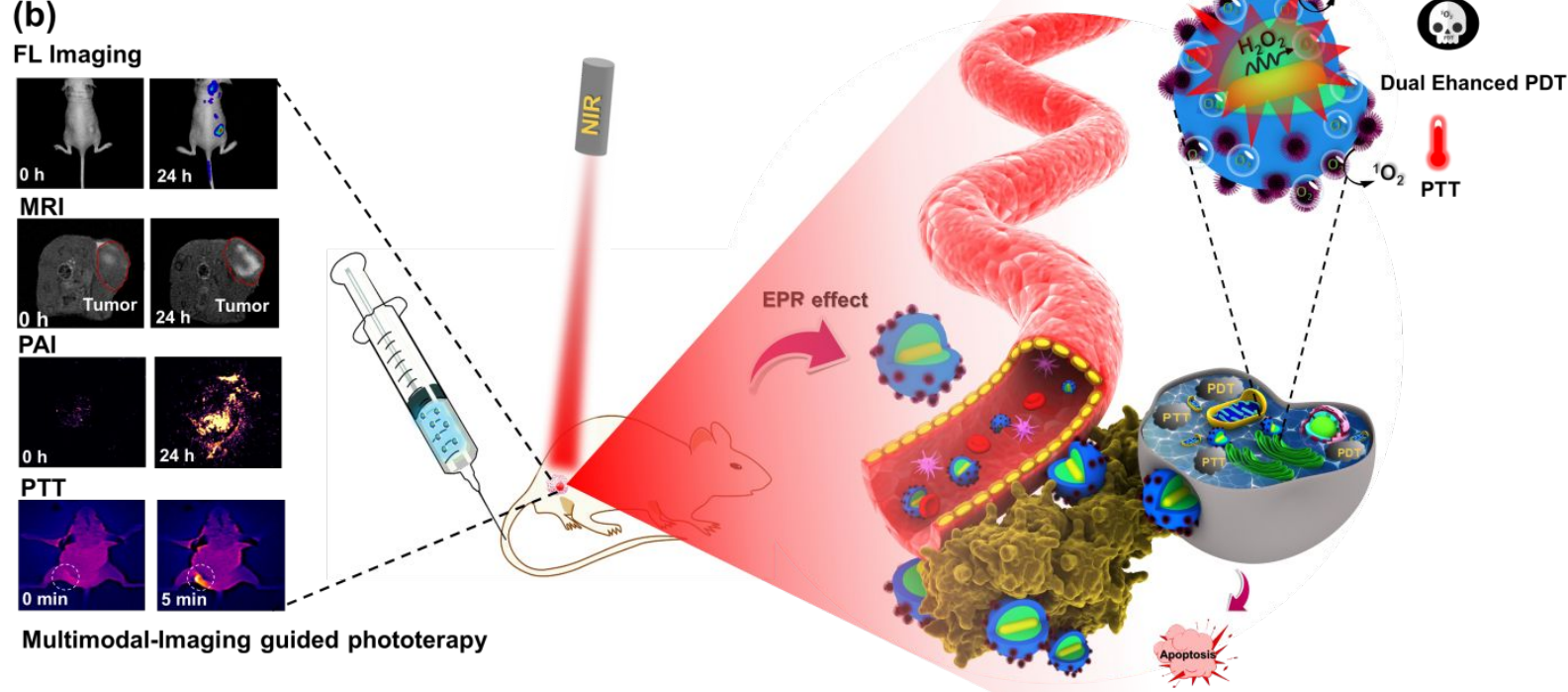

Scheme 1. Schematic of (a) synthetic process and (b) Multimodal-Imaging guided therapeutic effect of $\mathrm{Au} @ \mathrm{~PB} @ \mathrm{Cu}_{2} \mathrm{O} @ \mathrm{BPQDs} / \mathrm{PAH} \mathrm{NCs}$.

TEM images of obtained Au@PB NPs showed that the PB shell was well coated on the surface of Au NRs (about $110 \mathrm{~nm}$ ) with a $10 \mathrm{~nm}$ thick layer (Figure 1a), and its elemental mapping images (Figure 1b) displayed the good distributions of the $\mathrm{Au}, \mathrm{Fe}$, and $\mathrm{N}$ elements. The TEM, interfacial high-resolution TEM (HR-TEM) and elemental mapping images of $\mathrm{Au} @ \mathrm{~PB} @ \mathrm{Cu}_{2} \mathrm{O}$ core-shell NPs with well size $(250 \pm 20 \mathrm{~nm})$ and elements $(\mathrm{Au}, \mathrm{Fe}, \mathrm{Cu})$ dispersion were shown in Figure 1c, 
1d. The clearly exposed (111) plane and a lattice fringe spacing of $0.24 \mathrm{~nm}$ (Figure 1c), which belongs to $\mathrm{Cu}_{2} \mathrm{O}$ small crystalline, verified that $\mathrm{Cu}_{2} \mathrm{O}$ shell has been successfully coated on the surface of Au@PB NPs. While the PB layer could not be observed clearly due to the contrast between AuNR and $\mathrm{Cu}_{2} \mathrm{O}$ shell. Besides, the formation of $\mathrm{Au} @ \mathrm{~PB} @ \mathrm{Cu}_{2} \mathrm{O}$ core-shell NPs were also confirmed by the FT-IR spectrum. Figure S2 shows the FT-IR absorption spectrum of the Au@PB@ $\mathrm{Cu}_{2} \mathrm{O}$ powder. The absorption band at $610 \mathrm{~cm}^{-1}$ showed the typical characteristics of $\mathrm{Cu}_{2} \mathrm{O}$, which belongs to the stretching vibration of $\mathrm{Cu}-\mathrm{O}$ bond..$^{39}$ The absorption peak at $2070 \mathrm{~cm}^{-1}$ showed the common characteristics of $\mathrm{PB}$, corresponding to the stretching vibration of the $\mathrm{CN}$ group. ${ }^{40}$

The BPQDs were synthesized based on the solvothermal method (Figure S3). Its morphology and size (obtained via statistical TEM analysis) were shown in Figure S4. The average size of BPQDs were about $2.8 \pm 0.8 \mathrm{~nm}$ (Figure S5). Three typical Raman peaks of BP (Figure S6) corresponded to the out-of-plane vibration mode $\mathrm{A}_{1 \mathrm{~g}}$ at $363.5 \mathrm{~cm}^{-1}$, the in-plane vibration modes $\mathrm{B}_{2 \mathrm{~g}}$ at $440.8 \mathrm{~cm}^{-1}$ and $\mathrm{A}_{2 \mathrm{~g}}$ at $467.0 \mathrm{~cm}^{-1}$. Figure $\mathrm{S} 7$ shows the $\mathrm{UV}$-vis spectrum of BPQDs dissolved in $200 \mathrm{~mL}$ NMP solution, indicating that the solvothermal method could achieve a large scale production of BPQDs. HR-TEM image in Figure 1e showed PAH-modified BPQDs. The lattice fringes were 0.34, corresponding to the (021) plane of the BP crystal. As shown in Figure 1e, the morphology and nanostructure of BPQDs/PAH coated $\mathrm{Au} @ \mathrm{~PB} @ \mathrm{Cu}_{2} \mathrm{O}$ did not change and the ultimate size of Au@PB@Cu $\mathrm{Cu}_{2} \mathrm{O} @$ BPQDs/PAH NCs were about $275 \pm 25$ nm (Figure 1g), which was suitable for biomedical uses. ${ }^{41-43}$ According to the elemental mapping images (Figure 1f) $\mathrm{Au}$, Fe (different valence state with $\mathrm{Fe}^{2+}$ and $\mathrm{Fe}^{3+}$ originated from Prussian Blue), $\mathrm{K}, \mathrm{Cu}$, and $\mathrm{P}$ elements were uniformly distributed. The energy-dispersive spectroscopy (EDS) spectrum of Au@PB@Cu $\mathrm{Cu}$ OBPQDs/PAH NCs further demonstrated the coexistence of Au, Fe, K, Cu, O and $\mathrm{P}$ elements (Figure S8). In addition to these characterizations, we also employed X-ray photoeletroscopy (XPS) to investigate the components of the core-shell nanostructure. From the Figure 1h, the obtained XPS survey images of $\mathrm{Au} @ \mathrm{~PB} @ \mathrm{Cu}_{2} \mathrm{O} @ \mathrm{BPQDs} / \mathrm{PAH} \mathrm{NCs}$ proved that the chemical composition corresponded well to the previous research. ${ }^{17,44}$ Two typical peaks located at $720.28 \mathrm{eV}(\mathrm{Fe} \mathrm{2p1/2)} \mathrm{and} \mathrm{714.18} \mathrm{eV} \mathrm{(Fe} \mathrm{2p3/2)} \mathrm{in} \mathrm{the} \mathrm{high-resolution} \mathrm{Fe} \mathrm{2p} \mathrm{spectrum}$ were attributed to the FeNx unit, while the peak at $707.08 \mathrm{eV}(\mathrm{Fe} 2 \mathrm{p} 3 / 2)$ could be attributed to the $\left[\mathrm{Fe}^{2+}(\mathrm{CN})_{6}\right]$ units of PB shell (Figure 1i). ${ }^{40} \mathrm{In}$ XPS spectrum of $\mathrm{Cu} 2 \mathrm{p}$, a typical peak at $931.68 \mathrm{eV}$ $\left(\mathrm{Cu}^{+} 2 \mathrm{p} 3 / 2\right)$ and an obvious peak at $951.58 \mathrm{eV}\left(\mathrm{Cu}^{+} 2 \mathrm{p} 1 / 2\right)$ was displayed in Figure $1 \mathrm{j}$, which was 
due to the existence of $\mathrm{Cu}_{2} \mathrm{O}$, whereas the weak peak at about $943.18 \mathrm{eV}$ was due to the existence of $\mathrm{Cu}^{2+}{ }^{45}$ The inconspicuous peak belongs to $\mathrm{Au} 4 \mathrm{f}$ in Figure S9, which might be shielded by the $\mathrm{Cu}_{2} \mathrm{O}$ shell. Most importantly, we could still see two peaks at around $130.67 \mathrm{eV}(\mathrm{P} 2 \mathrm{p} 1 / 2)$ and $129.27 \mathrm{eV}(\mathrm{P} 2 \mathrm{p} 3 / 2)$ in Figure S10. ${ }^{46}$ A peak at high energy region (around $132.98 \mathrm{eV}$ ) indicated the oxidation of BPQDs. All TEM, EDS, XPS, and FT-IR results illustrated above demonstrated the successful fabrication of $\mathrm{Au} @ \mathrm{~PB} @ \mathrm{Cu}_{2} \mathrm{O} @ \mathrm{BPQDs} / \mathrm{PAH} \mathrm{NCs}$.

(a)

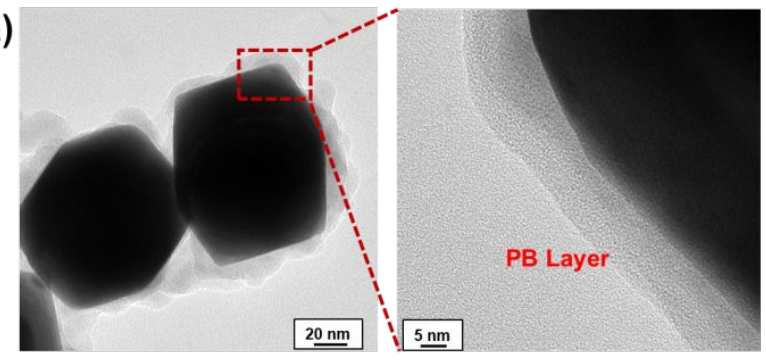

(b)
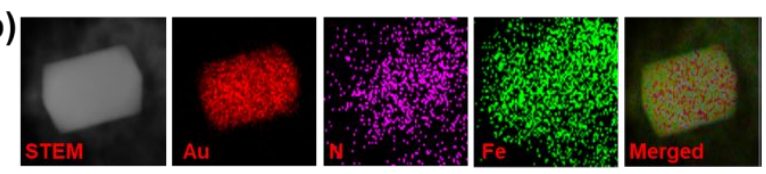

(e)
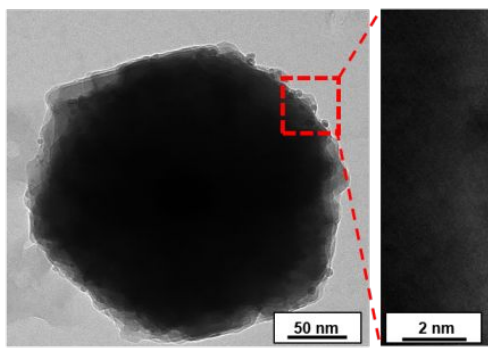

(c)

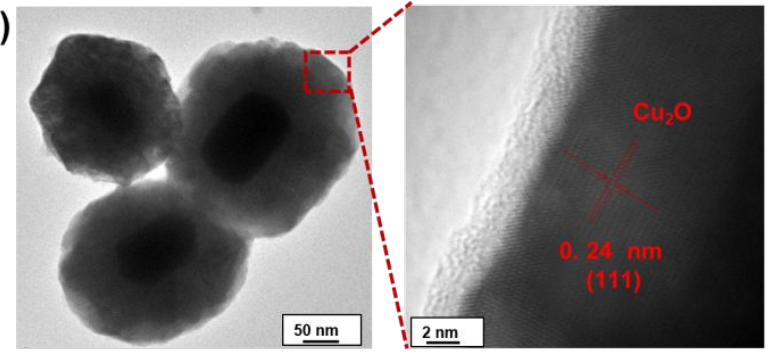

(d)

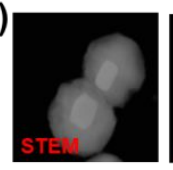

(f)
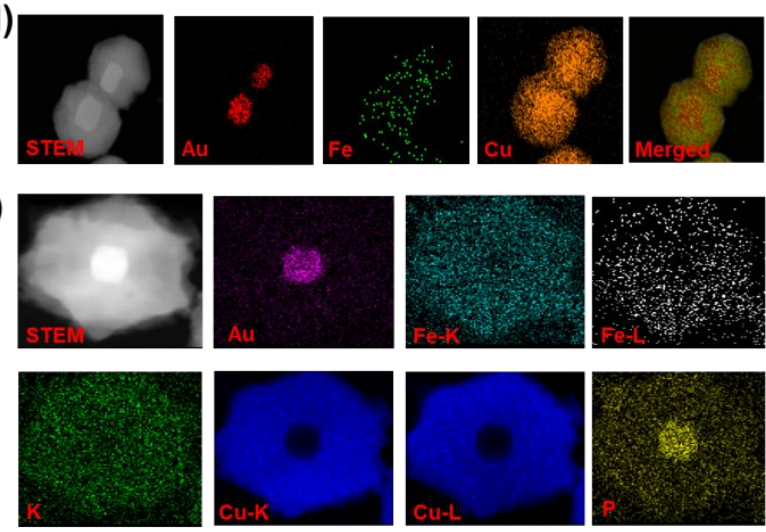

(g)
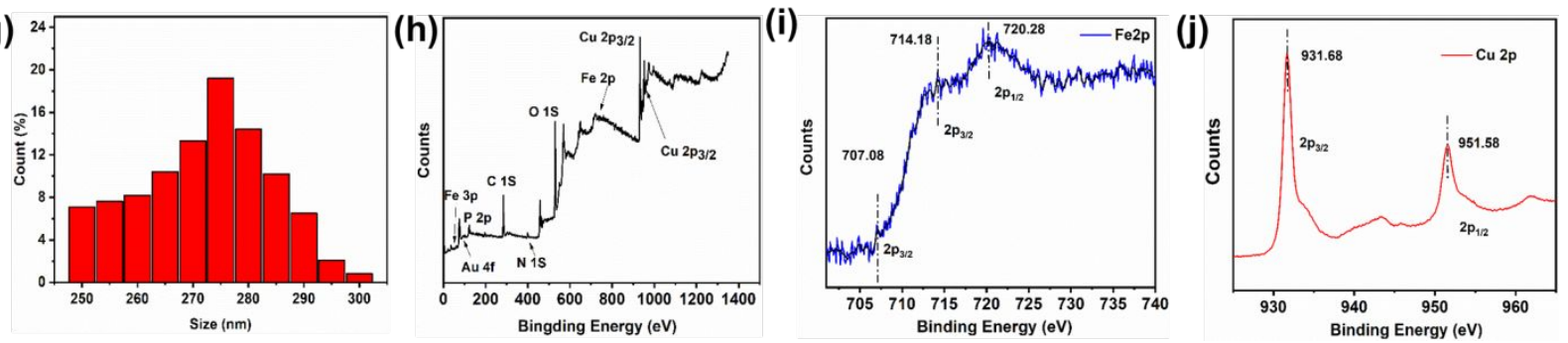

Figure 1. Characterization of $\mathrm{Au} @ \mathrm{~PB} @ \mathrm{Cu}_{2} \mathrm{O} @ \mathrm{BPQDs} / \mathrm{PAH}$ NCs. (a) TEM image and HR-TEM image of Au@PB NPs. (b) HAADF-STEM image and elemental mapping of Au@PB NPs. (c) TEM image and HR-TEM image of $\mathrm{Au} @ \mathrm{~PB} @ \mathrm{Cu}_{2} \mathrm{O}$ NPs. (d) HAADF-STEM image and elemental mapping of $\mathrm{Au} @ \mathrm{~PB} @ \mathrm{Cu}_{2} \mathrm{O}$ NPs. (e) TEM image and HR-TEM image of $\mathrm{Au} @ \mathrm{~PB} @ \mathrm{Cu}_{2} \mathrm{O} @ \mathrm{BPQDs} / \mathrm{PAH}$ NCs. Inset: HR-TEM images of BPQDs. (f) HAADF-STEM image and elemental mapping of $\mathrm{Au} @ \mathrm{~PB} @ \mathrm{Cu}_{2} \mathrm{O} @ \mathrm{BPQDs} / \mathrm{PAH}$ NCs. (g) Statistical analysis of the lateral sizes $\mathrm{Au} @ \mathrm{~PB} @ \mathrm{Cu}_{2} \mathrm{O} @ \mathrm{BPQD} / \mathrm{PAH}$ NCs determined by TEM. (h) XPS survey. (i) XPS spectrum of Fe 2p. (j) XPS image of $\mathrm{Cu} 2 \mathrm{p}$ of $\mathrm{Au} @ \mathrm{~PB} @ \mathrm{Cu}_{2} \mathrm{O} @ \mathrm{BPQDs} / \mathrm{PAH}$ NCs. 
Stability Assay of Au@PB@Cu $\mathbf{O} @$ OBPDs/PAH NCs. When the nanocomposites are applied as potential anticancer agents, it is essential to test its biostability in mimetic human body system. After cultivating with $\mathrm{H}_{2} \mathrm{O}, 10 \%$ fetal bovine serum, and phosphate buffered saline (PBS) with different time interval (6h, 12h, 24h, 48h), respectively, the biostability of the nanocomposite was evaluated by observing the UV-vis absorption changes when dissolving them in above selected solutions. From the supporting information (Figure S11a, 11b, 11c), there was no obvious change of absorption curves in $\mathrm{H}_{2} \mathrm{O}, 10 \%$ fetal bovine serum, and PBS. The above biostability analysis results suggested that $\mathrm{Au} @ \mathrm{~PB} @ \mathrm{Cu}_{2} \mathrm{O} @ \mathrm{BPQDs} / \mathrm{PAH}$ NCs possessed excellent stability in simulative liquid system.

Catalytic performance of $\mathrm{Au} @ \mathrm{~PB} @ \mathrm{Cu}_{2} \mathrm{O} @ \mathrm{BPQDs} / \mathrm{PAH}$ NCs for Generating $\mathrm{O}_{2}$. When $\mathrm{Au} @ \mathrm{~PB} @ \mathrm{Cu}_{2} \mathrm{O} @ \mathrm{BPQD} / \mathrm{PAH} \mathrm{NCs}$ were added to $20 \% \mathrm{H}_{2} \mathrm{O}_{2}$ at $20{ }^{\circ} \mathrm{C}$, plenty of bubbles were observed. By contrast, no bubbles were ovserved in the tube when $20 \% \mathrm{H}_{2} \mathrm{O}_{2}$ solution was added into the PBS solution without $\mathrm{Au} @ \mathrm{~PB} @ \mathrm{Cu}_{2} \mathrm{O} @ \mathrm{BPQDs} / \mathrm{PAH} \mathrm{NCs}$, which could be evaluated by the amount of dissolved $\mathrm{O}_{2}$ in two different solution (Figure 2a). Besides, the size of the bubbles became bigger and bigger with increasing of reaction time to $5 \mathrm{~min}$ (Figure S12). It verified the ability of $\mathrm{Au} @ \mathrm{~PB} @ \mathrm{Cu}_{2} \mathrm{O} @ \mathrm{BPQD} / \mathrm{PAH} \mathrm{NCs}$ to catalyze the decomposition of $\mathrm{H}_{2} \mathrm{O}_{2}$ into $\mathrm{O}_{2}$ and directly demonstrated that $\mathrm{Au} @ \mathrm{~PB} @ \mathrm{Cu}_{2} \mathrm{O} @ \mathrm{BPQDs} / \mathrm{PAH}$ NCs played a catalytic role in the decomposition of $\mathrm{H}_{2} \mathrm{O}_{2}$.

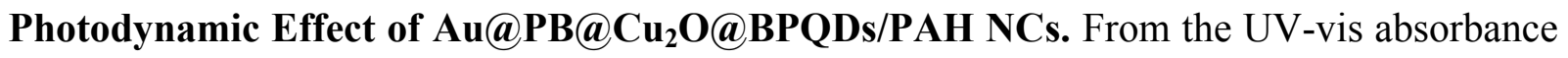
spectrum of $\mathrm{Au}$ nanorods, $\mathrm{Au} @ \mathrm{~PB} \mathrm{NPs}, \mathrm{Au} @ \mathrm{~PB} @ \mathrm{Cu}_{2} \mathrm{O}$ NPs, $\mathrm{Au} @ \mathrm{Cu}_{2} \mathrm{O}$ NPs, and Au@PB@ $\mathrm{Cu}_{2} \mathrm{O} @ B$ BPDs/PAH NCs (Figure 2b), we can see that the $\mathrm{Au} @ \mathrm{Cu}_{2} \mathrm{O}$ NPs exhibited a low absorption through the absorbance range $(300-900 \mathrm{~nm})$, while after the modification by the PB and BPQDs, the $\mathrm{Au} @ \mathrm{~PB} @ \mathrm{Cu}_{2} \mathrm{O} @ \mathrm{BPQD} / \mathrm{PAH}$ NCs showed a significant absorption in the NIR I window $(650-950 \mathrm{~nm}) .{ }^{47}$ In order to evaluate the PDT efficiency of $\mathrm{Au} @ \mathrm{~PB} @ \mathrm{Cu}_{2} \mathrm{O} @ \mathrm{BPQDs} / \mathrm{PAH} \mathrm{NCs}$, its ${ }^{1} \mathrm{O}_{2}$ production capacity was tested by using 1,3diphenylisobenzofuran (DPBF), a common standard regent for the determination of ${ }^{1} \mathrm{O}_{2}$. Firstly, as presented in Figure 2c, the absorption spectrum of DPBF decreased with the increasing irradiation with $650 \mathrm{~nm}$ laser $\left(0.5 \mathrm{~W} / \mathrm{cm}^{2}\right)$. The ${ }^{1} \mathrm{O}_{2}$ generation from $\mathrm{H}_{2} \mathrm{O}_{2}, \mathrm{Au} @ \mathrm{~PB}, \mathrm{Au} @ \mathrm{Cu}_{2} \mathrm{O}$, Au@PB@Cu $\mathrm{Cu}_{2} \mathrm{O}, \mathrm{Au} @ \mathrm{~PB} @ \mathrm{Cu}_{2} \mathrm{O} @ \mathrm{BPQD} / \mathrm{PAH}$ NCs, and Au@PB@ $@ \mathrm{Cu}_{2} \mathrm{O} @ \mathrm{BPQD} / \mathrm{PAH}$ NCs plus $\mathrm{H}_{2} \mathrm{O}_{2}$ when exposed to the $650 \mathrm{~nm}$ laser were assessed via monitoring the time-dependent photodegradation of DPBF, as presented in Figure 2d. The absorbance intensity at $410 \mathrm{~nm}$ of 

two groups, the $\mathrm{Au} @ \mathrm{Cu}_{2} \mathrm{O}$ NPs showed a slightly increment of ${ }^{1} \mathrm{O}_{2}$ production within 5 min according to the absorption at $410 \mathrm{~nm}$. While the steep downtrend were obtained for $\mathrm{Au} @ \mathrm{~PB} @ \mathrm{Cu}_{2} \mathrm{O}$ and $\mathrm{Au} @ \mathrm{~PB} @ \mathrm{Cu}_{2} \mathrm{O} @ \mathrm{BPQDs} / \mathrm{PAH} \mathrm{NCs}$, and $\mathrm{Au} @ \mathrm{~PB} @ \mathrm{Cu}_{2} \mathrm{O} @ \mathrm{BPQDs} / \mathrm{PAH}$ $\mathrm{NCs}$ plus $\mathrm{H}_{2} \mathrm{O}_{2}$ group. The latter generated much more ${ }^{1} \mathrm{O}_{2}$ generation than that of $\mathrm{Au} @ \mathrm{~PB} @ \mathrm{Cu}_{2} \mathrm{O}$ and $\mathrm{Au} @ \mathrm{~PB} @ \mathrm{Cu}_{2} \mathrm{O} @ \mathrm{BPQDs} / \mathrm{PAH}$ groups within 5 min under laser light, since in the presence of $\mathrm{H}_{2} \mathrm{O}_{2}$, a large amount of $\mathrm{O}_{2}$ generating from $\mathrm{PB}$ catalyzing $\mathrm{H}_{2} \mathrm{O}_{2}$ then reacted with $\mathrm{Cu}_{2} \mathrm{O}$ and BPQDs to generate efficient ${ }^{1} \mathrm{O}_{2}$. The proposed mechanism of enhanced photodynamic effect of $\mathrm{Au} @ \mathrm{~PB} @ \mathrm{Cu}_{2} \mathrm{O} @ \mathrm{BPQDs} / \mathrm{PAH}$ NCs are schematically illustrated in Figure 2e. Generally, $\mathrm{Cu}_{2} \mathrm{O}$ NPs can not be excited to generate ${ }^{1} \mathrm{O}_{2}$, since its band gap is less than the energy of $650 \mathrm{~nm}$ laser. In $\mathrm{Au} @ \mathrm{~PB} @ \mathrm{Cu}_{2} \mathrm{O} @ \mathrm{BPQDs} / \mathrm{PAH}$ and $\mathrm{Au} @ \mathrm{Cu}_{2} \mathrm{O}$ NPs, the Au nanorods can convert the energy absorbed from laser light into LSPR oscillations. The generated energy from Au nanorods, which was then directly delivered to the $\mathrm{Cu}_{2} \mathrm{O}$ shell, can induce the generation of electron-hole pairs in $\mathrm{Cu}_{2} \mathrm{O} \cdot{ }^{20,21}$ The generated electrons in $\mathrm{Cu}_{2} \mathrm{O}$ can then react with $\mathrm{O}_{2}$ to generate ${ }^{1} \mathrm{O}_{2} \cdot{ }^{22}$ The existence of $\mathrm{PB}$ layer in $\mathrm{Au} @ \mathrm{Cu}_{2} \mathrm{O}$ nanostructures can restrain the interfacial damping and the dephasing of the plasmon from hot-electron transfer as well as the back charge transfer, ensuring the nonradiative transfer of plasmonic energy from the $\mathrm{Au} N \mathrm{NR}$ core to $\mathrm{Cu}_{2} \mathrm{O}$ shell and enhanced the ${ }^{1} \mathrm{O}_{2}$ production through the PDT. In addition, the BPQDs also enhanced the generation of ${ }^{1} \mathrm{O}_{2}$. Attributed to the catalytic property of $\mathrm{PB}$, the resulting $\mathrm{NCs}$ successfully achieved $\mathrm{O}_{2}$ self-supply via catalyzing $\mathrm{H}_{2} \mathrm{O}_{2}$, which overcame the problem of the hypoxic microenvironment in tumor site, and improved PDT efficacy.

Electron spin resonance (ESR) spectrum was further employed to prove the above mechanism of the ${ }^{1} \mathrm{O}_{2}$ generation of $\mathrm{Au} @ \mathrm{~PB} @ \mathrm{Cu}_{2} \mathrm{O} @ \mathrm{BPQDs} / \mathrm{PAH}$ NCs by using the TEMP to trap ${ }^{1} \mathrm{O}_{2}$. The $\mathrm{Au} @ \mathrm{Cu}_{2} \mathrm{O} \mathrm{NPs}, \mathrm{Au} @ \mathrm{~PB}$ NPs, $\mathrm{Au} @ \mathrm{~PB} @ \mathrm{Cu}_{2} \mathrm{O}$ NPs, $\mathrm{Au} @ \mathrm{~PB} @ \mathrm{Cu}_{2} \mathrm{O} @ \mathrm{BPQDs} / \mathrm{PAH}$ NCs, and $\mathrm{Au} @ \mathrm{~PB} @ \mathrm{Cu}_{2} \mathrm{O} @ \mathrm{BPQDs} / \mathrm{PAH} \mathrm{NCs}$ plus $\mathrm{H}_{2} \mathrm{O}_{2}$ were exposed to $650 \mathrm{~nm}$ laser light, and $\mathrm{Au} @ \mathrm{~PB} @ \mathrm{Cu}_{2} \mathrm{O} @ \mathrm{BPQDs} / \mathrm{PAH} \mathrm{NCs}$ without 650 nm laser light were set as control groups, respectively. From ESR spectrum, there was an obvious signal peak which belongs to ${ }^{1} \mathrm{O}_{2}$ species, was detected from the $\mathrm{Au} @ \mathrm{~PB} \quad \mathrm{NPs}, \quad \mathrm{Au} @ \mathrm{Cu}_{2} \mathrm{O} \quad \mathrm{NPs}, \quad \mathrm{Au} @ \mathrm{~PB} @ \mathrm{Cu}_{2} \mathrm{O} \quad \mathrm{NPs}$, $\mathrm{Au} @ \mathrm{~PB} @ \mathrm{Cu}_{2} \mathrm{O} @ \mathrm{BPQDs} / \mathrm{PAH} \mathrm{NCs}$, and $\mathrm{Au} @ \mathrm{~PB} @ \mathrm{Cu}_{2} \mathrm{O} @ \mathrm{BPQDs} / \mathrm{PAH}$ NCs plus $\mathrm{H}_{2} \mathrm{O}_{2}$ after irradiation with $650 \mathrm{~nm}$ laser light, and $\mathrm{Au} @ \mathrm{~PB} @ \mathrm{Cu}_{2} \mathrm{O} @ \mathrm{BPQDs} / \mathrm{PAH} \mathrm{NCs}$ plus $\mathrm{H}_{2} \mathrm{O}_{2}$ group showed great intensity of signal peak compared to other 4 groups. This was because a large amount 
of $\mathrm{O}_{2}$ catalyzed by $\mathrm{PB}$ finally converted to ${ }^{1} \mathrm{O}_{2}$ when reacted with $\mathrm{Cu}_{2} \mathrm{O}$ shell and BPQDs, whereas no observable signals could be detected from Au@PB@ $\mathrm{Cu}_{2} \mathrm{O} @ \mathrm{BPQD} / \mathrm{PAH}$ NCs without 650 $\mathrm{nm}$ laser light irradiation. These results sufficiently confirmed the proposed mechanism of $\mathrm{O}_{2}$ generation and ${ }^{1} \mathrm{O}_{2}$ production ability of $\mathrm{Au} @ \mathrm{~PB} @ \mathrm{Cu}_{2} \mathrm{O} @ \mathrm{BPQDs} / \mathrm{PAH}$ NCs (Figure 2f).

The photodynamic properties of prepared samples were evaluated in intracellular experiments, as shown in Figure 2g. Herein, 2,7-dichlorofluorescin diacetate (DCFH-DA) has been extensively applied in detecting the generation of ${ }^{1} \mathrm{O}_{2}$ inside cells. Briefly, DCFH-DA, a type of ROS responsive probe with no fluorescence, can be converted to DCF with the oxidization by ${ }^{1} \mathrm{O}_{2}$ and then presents green fluorescence under $488 \mathrm{~nm}$ stimulation. From Figure $2 \mathrm{~g}$, the CLSM images of HeLa cells dealt with $\mathrm{Au} @ \mathrm{~PB} @ \mathrm{Cu}_{2} \mathrm{O} @ \mathrm{BPQD} / \mathrm{PAH} \mathrm{NCs}$ plus $\mathrm{H}_{2} \mathrm{O}_{2}$ under 650 nm laser light irradiation exhibited prominent bright green fluorescence with higher fluorescence intensity than the Au@PB@Cu $\mathrm{Cu}_{2} \mathrm{O} @ \mathrm{BPQDs} / \mathrm{PAH} \mathrm{NCs}$ and $\mathrm{Au} @ \mathrm{~PB} @ \mathrm{Cu}_{2} \mathrm{O}$ NPs groups. In contrast, the Hela cells cultivated with normal saline (control group), $\mathrm{H}_{2} \mathrm{O}_{2}$ as well as with $\mathrm{Au} @ \mathrm{Cu}_{2} \mathrm{O}$ NPs exhibited almost invisible or weak green fluorescence, which further indicates that $\mathrm{Au} @ \mathrm{~PB} @ \mathrm{Cu}_{2} \mathrm{O} @ \mathrm{BPQDs} / \mathrm{PAH}$ NCs can serve as efficient photodynamic agent.

Photothermal Effect of Au@PB@Cu 0 OBPQDs/PAH NCs. The photothermal performance of the nanocomposite was studied using a $650 \mathrm{~nm}$ laser $\left(1.5 \mathrm{~W} / \mathrm{cm}^{2}\right)$ as light source through the whole experiments. As presented in Figure 3a, the temperature of $\mathrm{Au} @ \mathrm{~PB} @ \mathrm{Cu}_{2} \mathrm{O} @ \mathrm{BPQDs} / \mathrm{PAH}$ $\mathrm{NCs}$ at different concentrations increased quickly after $5 \mathrm{~min}$ of laser $\left(1.5 \mathrm{~W} / \mathrm{cm}^{2}\right)$ irradiation, showing a concentration-dependent photothermal effect. Especially for the concentration of 200 $\mu \mathrm{g} / \mathrm{mL}$, the temperature increased to $52.5^{\circ} \mathrm{C}$. However, there was no apparent temperature increase was observed in the deionized water. Infrared thermal images were taken to further detect temperature changes and evaluate the photothermal effect, as shown in Figure 3b. Obviously, the temperature of $\mathrm{Au} @ \mathrm{~PB} @ \mathrm{Cu}_{2} \mathrm{O} @ \mathrm{BPQDs} / \mathrm{PAH} \mathrm{NCs}$ after irradiation increased by $27.5{ }^{\circ} \mathrm{C}$. The photothermal conversion efficiency of $\mathrm{Au} @ \mathrm{~PB} @ \mathrm{Cu}_{2} \mathrm{O} @ \mathrm{BPQDs} \mathrm{NCs}$ was studied. Figure 3c showed the temperature curve with an exposure time of 5 min irradiation, followed by another 10 min without irradiation. The linear time data versus $\ln (\theta)$ obtained during the cooling time (Figure 3d) was used to assess its heat transfer effect. ${ }^{48}$ Comparing to other PTT agents, Au@PB@ $\mathrm{Cu}_{2} \mathrm{O} @ \mathrm{BPQDs} / \mathrm{PAH}$ NCs possessed a higher photothermal conversion efficiency $(\eta)$ of $25.73 \%$, while $\eta$ was $13 \%$ for Au nanoshells, ${ }^{49}$ and $22 \%$ for $\mathrm{Cu}_{2-\mathrm{x}} \mathrm{Se} .{ }^{50}$ 
(a)

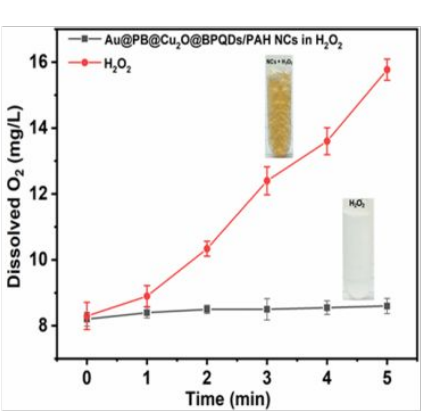

(d)

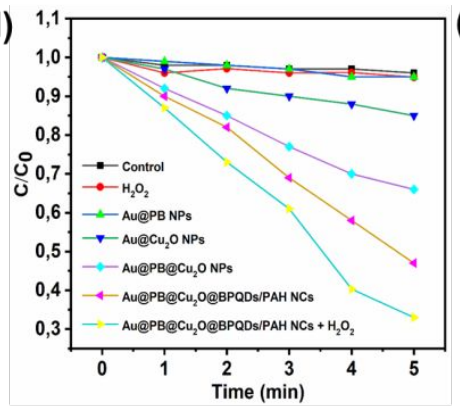

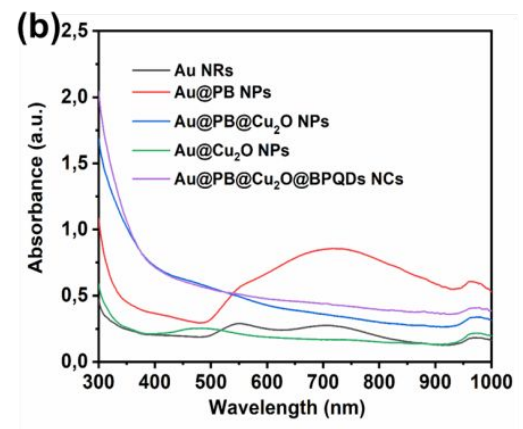

(e)

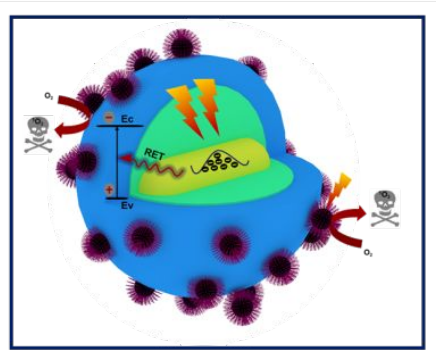

(c)

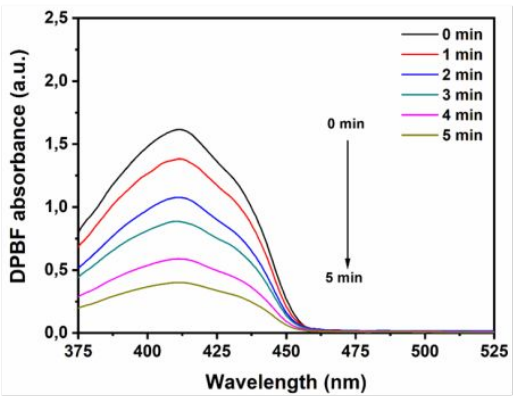

(f)

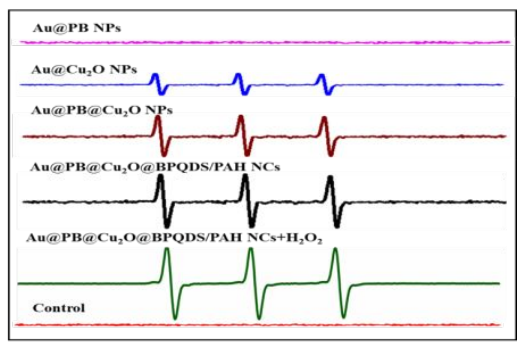

(g)
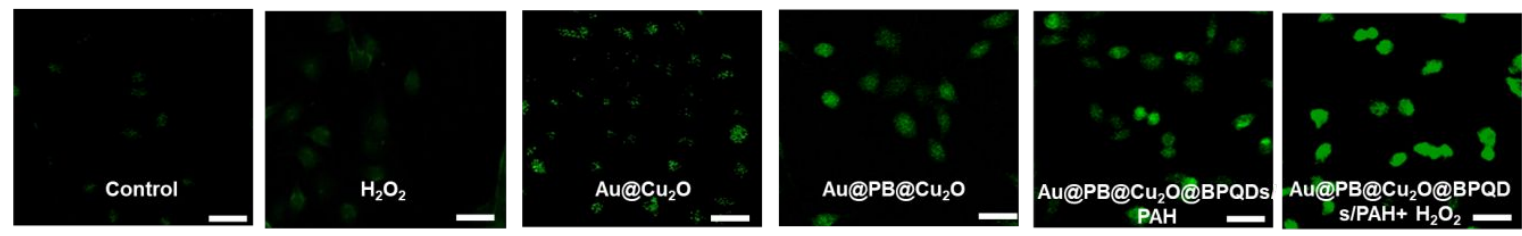

Figure 2. (a) The concentration changes of dissolved $\mathrm{O}_{2}$ with the increase of reaction time. Inset: the photo of the mixture of $\mathrm{Au} @ \mathrm{~PB} @ \mathrm{Cu}_{2} \mathrm{O} @$ BPQDs/PAH NCs and $\mathrm{H}_{2} \mathrm{O}_{2}$ solution in the PBS, the $\mathrm{H}_{2} \mathrm{O}_{2}$ solution in the PBS without the NCs. (b) UV-vis absorption spectra of Au NRs, Au@PB NPs, Au@PB@ $\mathrm{Cu}_{2} \mathrm{O}$ NPs, Au@Cu $\mathrm{Cu}$ NPs, and

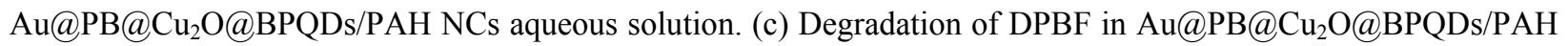
NCs solution under $650 \mathrm{~nm}$ laser $\left(0.5 \mathrm{~W} / \mathrm{cm}^{2}\right)$ irradiation at each point time. (d) Time-dependent degradation of DPBF at 410 nm caused by ${ }^{1} \mathrm{O}_{2}$ generated by $\mathrm{H}_{2} \mathrm{O}_{2}, \mathrm{Au} @ \mathrm{Cu}_{2} \mathrm{O} \mathrm{NPs}, \mathrm{Au} @ \mathrm{~PB} @ \mathrm{Cu}_{2} \mathrm{O} \mathrm{NPs}, \mathrm{Au} @ \mathrm{~PB} @ \mathrm{Cu} 2 \mathrm{O} @ \mathrm{BPQDs} / \mathrm{PAH}$ $\mathrm{NCs}$, and $\mathrm{Au} @ \mathrm{~PB} @ \mathrm{Cu}_{2} \mathrm{O} @ \mathrm{BPQDs} / \mathrm{PAH}$ NCs plus $\mathrm{H}_{2} \mathrm{O}_{2}$ under 650 nm laser irradiation. (e) Proposed mechanism of enhanced photodynamic effect of Au@PB@Cu $\mathrm{C} @$ $@$ BPQDs/PAH NCs. (f) ESR spectra of Au@PB NPs, Au@Cu $\mathrm{A}$ NPs, Au@PB@ $\mathrm{Cu}_{2} \mathrm{O}$ NPs, $\mathrm{Au} @ \mathrm{~PB} @ \mathrm{Cu}_{2} \mathrm{O} @ \mathrm{BPQDs} / \mathrm{PAH} \mathrm{NCs}$, and Au@PB@ $\mathrm{Cu}_{2} \mathrm{O} @ \mathrm{BPQDs} / \mathrm{PAH} \mathrm{NCs} \mathrm{plus} \mathrm{H}_{2} \mathrm{O}_{2}$ in the presence of TEMP with or treated with $\mathrm{Au} @ \mathrm{~PB} @ \mathrm{Cu}_{2} \mathrm{O} @ \mathrm{BPQDs} / \mathrm{PAH}$ without irradiation for 5 min (650 nm, $0.5 \mathrm{~W} / \mathrm{cm}^{2}$ ). (g) CLSM images of HeLa cells after treat with different groups and then stained with DCFH-DA (ROS fluorescence probe), the scale bar was $50 \mu \mathrm{m}$.

The hemocompatibility of $\mathrm{Au} @ \mathbf{P B} @ \mathrm{Cu}_{2} \mathrm{O} @ \mathrm{BPQDs}$ NCs. The toxicity of the nanomaterials is a big concern when applied in biomedical field. Therefore, it is necessary to evaluate hemocompatibility of $\mathrm{Au} @ \mathrm{~PB} @ \mathrm{Cu}_{2} \mathrm{O} @ \mathrm{BPQDs} / \mathrm{PAH}$ NCs. In this work, red blood cells (RBCs) were selected to test the toxicity. Generally, monitoring the morphology change of RBCs is a standard method to evaluate the hemocompatibility. As presented in Figure 3e, RBCs incubated 
with phosphate buffered saline (PBS, as negative control group) and $\mathrm{Au} @ \mathrm{~PB} @ \mathrm{Cu}_{2} \mathrm{O} @ \mathrm{BPQDs} / \mathrm{PAH}$ NCs solutions with different concentrations, in deionized water (Figure S13, positive control) suffered destruction. There was no obvious morphology changes, destruction or aggregation, implying the samples possessed no side effect on RBCs. After RBCs experiments, hemolysis rate, as another important parameter, was further calculated. In normal conditions, hemolysis rate below $5 \%$ is allowable. It can be seen clearly from Figure $3 \mathrm{f}$ that the highest hemolysis rate corresponding to the highest concentrations of samples $(1000 \mu \mathrm{g} / \mathrm{mL})$ was up to $0.82 \%$, which was far less than the standard value (5\%), indicating Au@PB@ $\mathrm{Cu}_{2} \mathrm{O} @ B P Q D s / P A H ~ N C s$ caused negligible hemolysis effect.

(a)

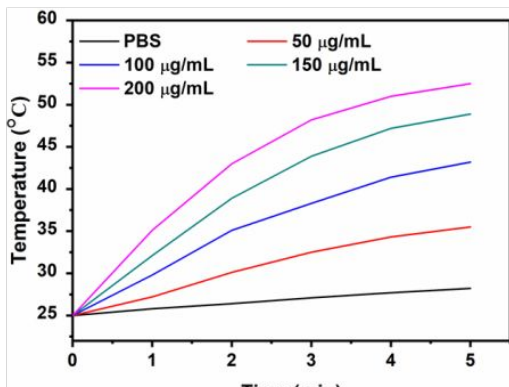

(d)

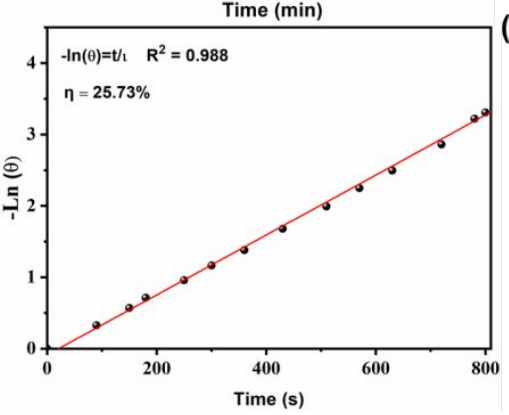

(b)
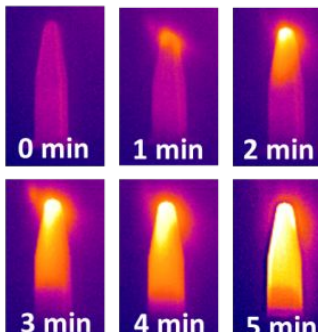

$2 \mathrm{~min}$

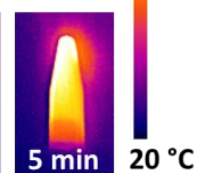

(e)

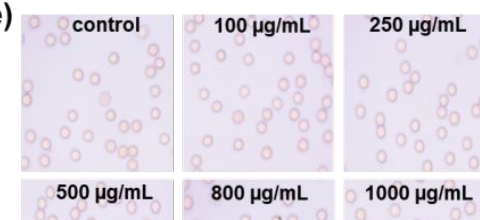

(c)
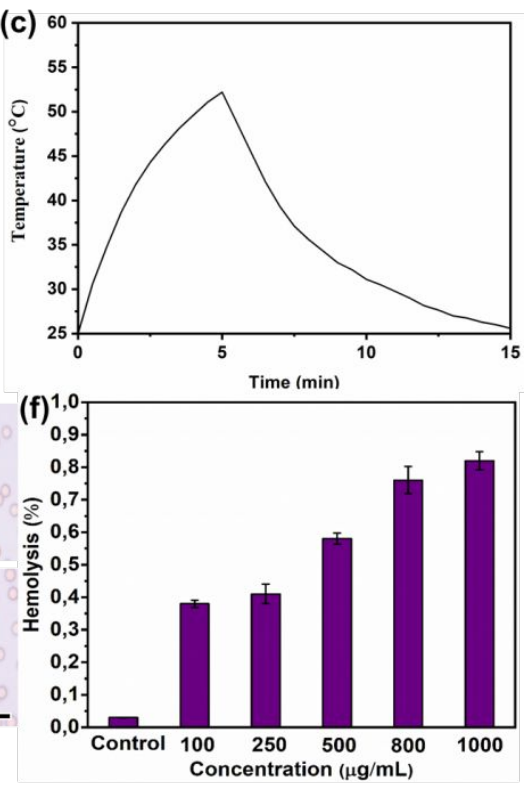

Figure 3. (a) Photothermal heating curves of PBS and $\mathrm{Au} @ \mathrm{~PB} @ \mathrm{Cu}_{2} \mathrm{O} @ \mathrm{BPQDs} / \mathrm{PAH}$ NCs in MiliQ water at different concentrations under $650 \mathrm{~nm}$ laser light $\left(1.5 \mathrm{~W} / \mathrm{cm}^{2}\right)$. (b) Infrared photothermal images of $\mathrm{Au} @ \mathrm{~PB} @ \mathrm{Cu}_{2} \mathrm{O} @ \mathrm{BPQDs} / \mathrm{PAH} \mathrm{NCs}$ at different irradiation time. (c) Photothermal response of $\mathrm{Au} @ \mathrm{~PB} @ \mathrm{Cu}_{2} \mathrm{O} @ \mathrm{BPQDs} / \mathrm{PAH} \mathrm{NCs}$ aqueous solution under irradiation for 5 min with an NIR laser $(650 \mathrm{~nm}, 1.5$ $\mathrm{W} / \mathrm{cm}^{2}$ ) and then the laser was shut off. d) Obtained time constant for heat transfer of this nanosystem ( $\tau \mathrm{s}=238.095$ s) by applying $-\ln (\theta)$ vs linear time data from the cooling stage. (e) The morphology of red blood cells treated with $\mathrm{Au} @ \mathrm{~PB} @ \mathrm{Cu}_{2} \mathrm{O} @ \mathrm{BPQDs} / \mathrm{PAH} \mathrm{NCs}$ at different concentrations, the scale bar was $50 \mu \mathrm{m}$. (f) Hemolytic assay of $\mathrm{Au} @ \mathrm{~PB} @ \mathrm{Cu}_{2} \mathrm{O} @ \mathrm{BPQDs} / \mathrm{PAH} \mathrm{NCs}$ by red blood cells.

\section{Evaluation Cytotoxicity and Ablation Performance of $\mathrm{Au} @ \mathrm{~PB} @ \mathrm{Cu}_{2} \mathrm{O} @ \mathrm{BPQDs} / \mathrm{PAH}$}

NCs. We evaluated the in vitro anticancer effect of $\mathrm{Au} @ \mathrm{~PB} @ \mathrm{Cu}_{2} \mathrm{O} @ \mathrm{BPQDs} / \mathrm{PAH} \mathrm{NCs}$. In order to investigate the cell uptake of resulting nanocomposites, we used CLSM to observe the red fluorescence intensity originated from Cyanine5.5-decorated $\mathrm{Au} @ \mathrm{~PB} @ \mathrm{Cu}_{2} \mathrm{O} @ \mathrm{BPQDs} / \mathrm{PAH} \mathrm{NCs}$ 
(Cy5.5@NCs). As shown in Figure 4a, strong red fluorescence could be observed inside cells after $3 \mathrm{~h}$ incubation, and homologous fluorescence signal distribution was marked by red cycle, demonstrating the high cellular uptake efficiency of Cy5.5@NCs. The in vitro cytotoxicity of Au@PB@ $\mathrm{Cu}_{2} \mathrm{O} @ \mathrm{BPQDs} / \mathrm{PAH} \quad \mathrm{NCs} \quad$ was studied by 3-(4,5dimethylthiazol-2-yl)-2,5diphenyltetrazolium bromide (MTT) assay. We selected two common types of cells (NIH3T3 cells and Hela cells) as experimental subjects to evaluate its cell viability under dark and laser light. As shown in Figure 4b, there was no apparent cytotoxicity against NIH3T3 cells and Hela cells after $24 \mathrm{~h}$ incubation with the resulting NCs without laser irradiation. In contrast, two different power laser light $\left(650 \mathrm{~nm}, 0.5 \mathrm{~W} / \mathrm{cm}^{2}, 1.5 \mathrm{~W} / \mathrm{cm}^{2}\right)$ were used to calculate the cells viability under irradiation. Hela cells were treated with either NCs only or NCs plus $\mathrm{H}_{2} \mathrm{O}_{2}$, so that four combinations of conditions were tested. As shown in Figure 4c, the four groups showed concentration-dependent dramatic decrease in the percentage of cell viability. It is worth noting, that the group with higher laser power and treated with $\mathrm{NCs}$ plus $\mathrm{H}_{2} \mathrm{O}_{2}$ gave the most rapid downtrend in cell viability. Almost $100 \%$ of the Hela cells were killed as a result of combined heat and the large amount of toxic ${ }^{1} \mathrm{O}_{2}$ generated with $650 \mathrm{~nm}$ laser light irradiation. In order to get more facts of the synergistic anticancer therapy effect, HeLa cells in there were stained with calcein-AM (live cells, green), and propidium iodide (dead cells, red). As shown in Figure 4d, HeLa cells incubated with Au@PB@Cu $2 \mathrm{O} @ B P Q D s / P A H ~ N C s$ irradiated with 650 nm laser light $\left(1.5 \mathrm{~W} / \mathrm{cm}^{2}\right)$ exhibited apparent killing effect in contrast to other control groups. In particular, the $\mathrm{NCs}$ at low concentration $\left(100 \mu \mathrm{g} / \mathrm{mL}, 650 \mathrm{~nm}, 1.5 \mathrm{~W} / \mathrm{cm}^{2}\right)$ still possessed severe apoptosis compared with the group of NCs at $250 \mu \mathrm{g} / \mathrm{mL}$ under $650 \mathrm{~nm}$ laser light $\left(1.5 \mathrm{~W} / \mathrm{cm}^{2}\right)$, which further demonstrated the catalytic performance of $\mathrm{Au} @ \mathrm{~PB} @ \mathrm{Cu}_{2} \mathrm{O} @ \mathrm{BPQDs} / \mathrm{PAH}$ NCs to catalyze $\mathrm{H}_{2} \mathrm{O}_{2}$ into $\mathrm{O}_{2}$ then generate a large amount of high toxic ${ }^{1} \mathrm{O}_{2}$. All the aforementioned results efficiently demonstrated the great biocompatibility and NIR-induced phototoxicity of $\mathrm{Au} @ \mathrm{~PB} @ \mathrm{Cu}_{2} \mathrm{O} @ \mathrm{BPQDs} / \mathrm{PAH} \mathrm{NCs}$.

In vivo Fluorescence, MR, and PA imaging performance. Before in vivo imaging experiments, the in vivo behaviors of $\mathrm{Au} @ \mathrm{~PB} @ \mathrm{Cu}_{2} \mathrm{O} @ \mathrm{BPQDs} / \mathrm{PAH} \mathrm{NCs}$ by measuring $\mathrm{Au}$ element using inductively coupled plasma atomic emission spectroscopy (ICP-AES). The blood was collected from mice at each time point and its levels of $\mathrm{Au} @ \mathrm{~PB} @ \mathrm{Cu}_{2} \mathrm{O} @ \mathrm{BPQDs} / \mathrm{PAH} \mathrm{NCs}$ showed a gradual decrease over time, while still maintained a high level of $\sim 4.3 \% \mathrm{ID} / \mathrm{g}$ even after 24 h injection (Figure S14). To monitor the biodistribution of the $\mathrm{Au} @ \mathrm{~PB} @ \mathrm{Cu}_{2} \mathrm{O} @ \mathrm{BPQDs} / \mathrm{PAH}$ 
NCs in vivo, the Cy5.5-decorated NCs were injected into mice by tail veins, and its biodistribution was directly observed by fluorescence imaging. From Figure 5a, we can clearly see the fluorescence signal from the tumor at $6 \mathrm{~h}$ post-injection, while the subcutaneous tumor could be definitely delineated from the other tissues. Besides, the fluorescence intensity located at tumor site exhibited a stable level, which was detected at $6 \mathrm{~h}, 12 \mathrm{~h}$, and $24 \mathrm{~h}$ post-injection (Figure $5 \mathrm{~b}$ ). Moreover, no obvious signal was detected in other tissues site, suggesting the $\mathrm{Au} @ \mathrm{~PB} @ \mathrm{Cu}_{2} \mathrm{O} @ \mathrm{BPQDs} / \mathrm{PAH} \mathrm{NCs}$ could continuously accumulate at the tumor site due to the enhanced permeability and retention (EPR) effect of cancerous tumors. ${ }^{51}$

(a)

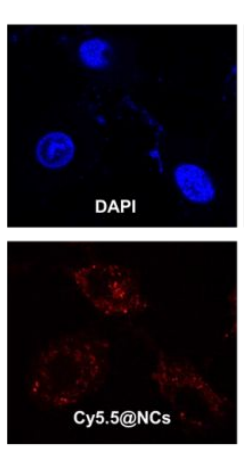

(c)

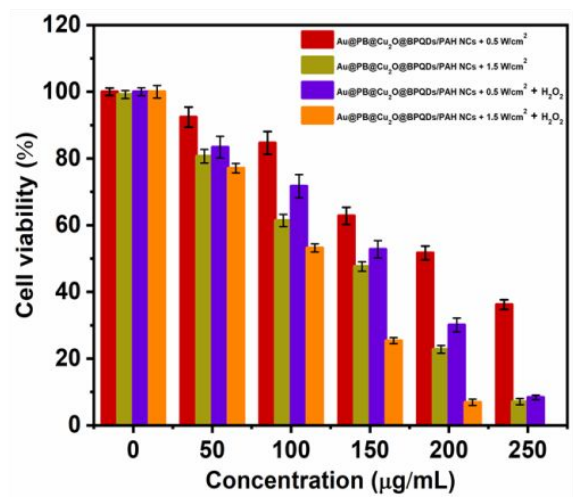

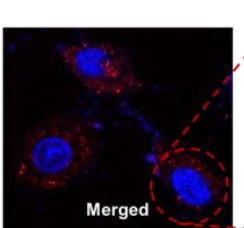
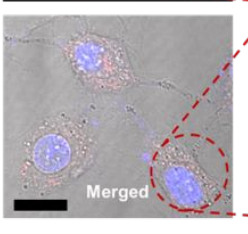

(b)

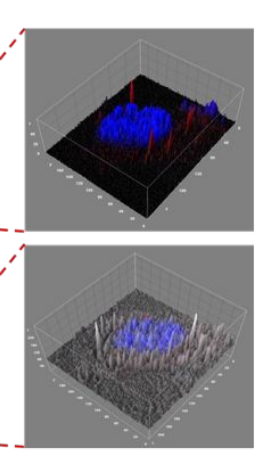

(d)
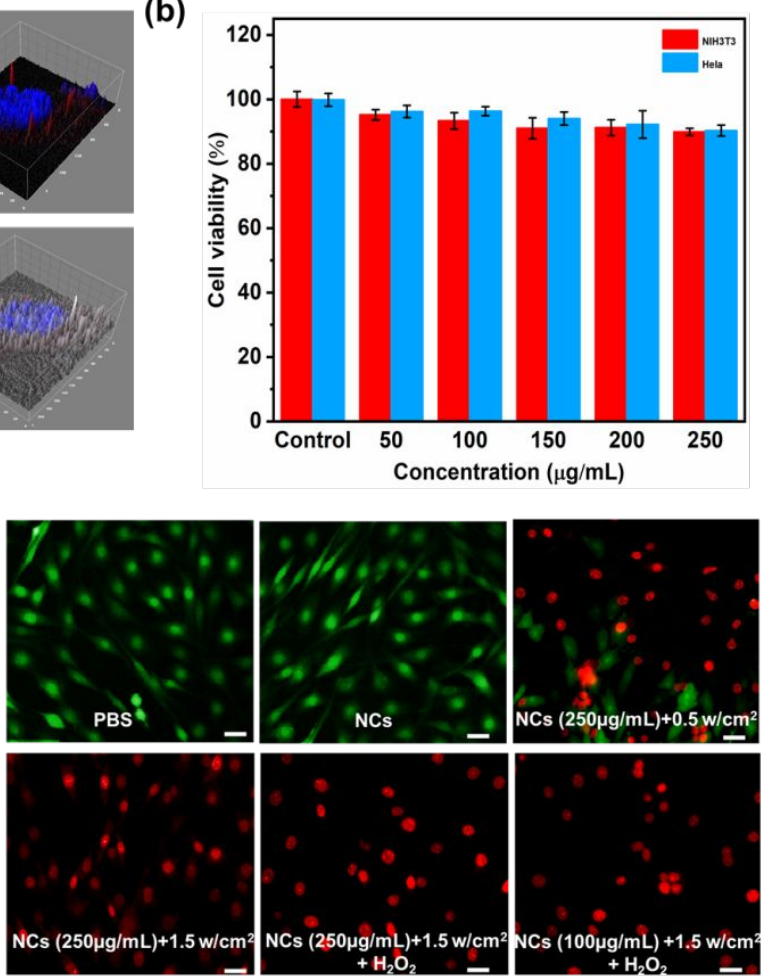

Figure 4. (a) CLSM images of HeLa cells incubated with Cyanine5.5-decorated $\mathrm{Au} @ \mathrm{~PB} @ \mathrm{Cu}_{2} \mathrm{O} @ \mathrm{BPQDs} / \mathrm{PAH} \mathrm{NCs}$ (Cy5.5@NCs) and fluorescence signal distribution of Cy5.5@NCs marked by red cycle. The scale bar is $10 \mu \mathrm{m}$. (b) Cytotoxicity of the Au@PB@ $\mathrm{Cu}_{2} \mathrm{O} @$ BPQDs/PAH NCs at different concentrations $(0-250 \mu \mathrm{g} / \mathrm{mL})$ after $24 \mathrm{~h}$ of incubation with NIH3T3 cells and Hela cells. (c) Cell viability of HeLa cells treated with $\mathrm{Au} @ \mathrm{~PB} @ \mathrm{Cu}_{2} \mathrm{O} @ \mathrm{BPQDs} / \mathrm{PAH} \mathrm{NCs}$ at different concentrations $(0-250 \mu \mathrm{g} / \mathrm{mL})$ irradiated with different power $(0.5$ $\mathrm{W} / \mathrm{cm}^{2}, 1.5 \mathrm{~W} / \mathrm{cm}^{2}$ ) of $650 \mathrm{~nm}$ laser light with $\mathrm{H}_{2} \mathrm{O}_{2}$ or without it. (d) Live/dead assay of HeLa cells after incubation with different groups. The scale bar is $50 \mu \mathrm{m}$.

Recently, $T_{1}$-weighted MRI that has great sensitivity to soft tissues, has been extensively used in bioimaging and cancer diagnosis application due to its excellent spatial resolution. It is well 
known that $\mathrm{Fe}^{3+}$ can be used as $T_{l}$-weighted MRI contrast agent by interacting the protons of water molecules. Since our $\mathrm{Au} @ \mathrm{~PB} @ \mathrm{Cu}_{2} \mathrm{O} @ \mathrm{BPQDs} / \mathrm{PAH} \mathrm{NCs}$ were equipped with the PB modified shell, they were able to be used for MR imaging. ${ }^{28}$

To study the potential application of $\mathrm{Au} @ \mathrm{~PB} @ \mathrm{Cu}_{2} \mathrm{O} @ \mathrm{BPQDs} / \mathrm{PAH} \mathrm{NCs}$ as $T_{1}$-MRI contrast agents, the $T_{l}$ relaxation times of $\mathrm{Au} @ \mathrm{~PB} @ \mathrm{Cu}_{2} \mathrm{O} @ \mathrm{BPQDs} / \mathrm{PAH} \mathrm{NCs}$ were tested. Consequently, the longitudinal relaxivity values $\left(\mathrm{r}_{1}\right)$, were calculated from the slope of the plot of $T_{1}$ vs sample molar concentration of [Fe], respectively. The longitudinal relaxation rate $\mathrm{r}_{1}$ was $5.578 \mathrm{mM}^{-1} \mathrm{~S}^{-1}$, (Figure S15). Next, after injection with $\mathrm{Au} @ \mathrm{~PB} @ \mathrm{Cu}_{2} \mathrm{O} @ \mathrm{BPQDs} / \mathrm{PAH} \mathrm{NCs}$ in different time interval ( $0 \mathrm{~h}, 6 \mathrm{~h}, 12 \mathrm{~h}, 24 \mathrm{~h}$ ), it was observed that $T_{l}$-weighted MR signals at tumor site enhanced obviously after $6 \mathrm{~h}$ post-injection (Figure $5 \mathrm{c}$ ). $T_{l}$-weighted MR intensity was scanned by a $3.0 \mathrm{~T}$ clinical MRI system. As shown in Figure S16, MR intensity located at tumor site increased to the maximum value (14676.7 \pm 1174.136$)$, and decreased a bit (13115.2 \pm 849.216$)$ after 24 h postinjection, which demonstrated the potential of $\mathrm{Au} @ \mathrm{~PB} @ \mathrm{Cu}_{2} \mathrm{O} @ \mathrm{BPQDs} / \mathrm{PAH}$ NCs NCs as a contrast material for $T_{1}$-weighted MR imaging.

Photoacoustic imaging as an emerging noninvasive imaging technique, has attracted extensive attentions. Suitable photoacoustic contrast agents should possess great photothermal effect as to minimize the light scattering effect and improve the signal-to-noise ratio (SNR). ${ }^{52}$ According to the previous work, PB NPs exhibited a high absorption in the NIR region, which tended to be a strong contrast agent for PA imaging. ${ }^{26,30,53}$ In this study, the obtained photoacoustic images from tumor site was monitored before and after the injection of $\mathrm{Au} @ \mathrm{~PB} @ \mathrm{Cu}_{2} \mathrm{O} @ \mathrm{BPQDs} / \mathrm{PAH} \mathrm{NCs}$ $(250 \mu \mathrm{g} / \mathrm{mL})$ into hela tumor bearing mice via tail veins. As shown in Figure 5d, the photoacoustic signals in tumor increased obviously after injection of $\mathrm{Au} @ \mathrm{~PB} @ \mathrm{Cu}_{2} \mathrm{O} @ \mathrm{BPQDs} / \mathrm{PAH}$ NCs due to the circulation of NPs in the blood. Besides, prominet photoacoustic signals emerged and scattered throughout the whole tumor, in which the total signals displayed a durable time-dependent increase, indicating the efficient tumor retention of $\mathrm{Au} @ \mathrm{~PB} @ \mathrm{Cu}_{2} \mathrm{O} @ \mathrm{BPQDs} / \mathrm{PAH}$ NCs. Therefore, introducing the PB layer into the traditional $\mathrm{Au} @ \mathrm{Cu}_{2} \mathrm{O}$ system not only enhanced PTT and PDT effect, but also achieved a $T_{1}$-weighted MRI, PAI-guided photodynamic therapy, which has never been reported in previous research. After evaluation of imaging performance in vivo, we further investigated the biodistribution of $\mathrm{Au} @ \mathrm{~PB} @ \mathrm{Cu}_{2} \mathrm{O} @ \mathrm{BPQD} / \mathrm{PAH} \quad \mathrm{NCs}$ by ICP-AES measurements of Au element in different organs. It can be seen from Figure S17, the tumor uptake of NCs was found to be relatively high, at a level of $\sim 14.9 \% \mathrm{ID} / \mathrm{g}$ at $24 \mathrm{~h}$ post injection, which 
could be attributed to the EPR effect of tumor tissues. As for other NCs' distribution in different organs, such NCs also showed high accumulation in the liver because of the macrophage clearance of NCs. What is more, the high Au level in the kidney indicated that these NCs could be excreted by renal excretion.

In vivo Tumor Ablation. The antitumor performance was further evaluated in vivo. Firstly, we selected infrared thermal imager to evaluate the in vivo PTT effects of our Au@PB@Cu $\mathrm{Cu}_{2} \mathrm{O} @$ BPQDs/PAH NCs in Hela-bearing tumor mice model (Figure 6a). After the tumor volume has reached ca. $100 \mathrm{~mm}^{3}, 12$ mice were randomly divided into two groups with tail veins of our NCs, and PBS, respectively. Animal NIR images and temperature changes $(\Delta \mathrm{T})$ were monitored during $5 \mathrm{~min}$ laser light $\left(650 \mathrm{~nm}, 1.5 \mathrm{~W} / \mathrm{cm}^{2}\right)$ irradiation. Image $J$ software was used to detect the tissue penetration of $650 \mathrm{~nm}$ laser light. As presented in Figure $6 \mathrm{~b}, \Delta \mathrm{T}$ of injected PBS group was only 0.61 , while that of NCs were 16.9 throughout the whole irradiation period, which was attribute to the great absorption in at $650 \mathrm{~nm}$ and high photothermal conversion efficiency, indicating that our samples maintained an excellent photothermal effect when injected into mice model. The antitumor effect was evaluated based on the relative change of tumor volumes.

(a)
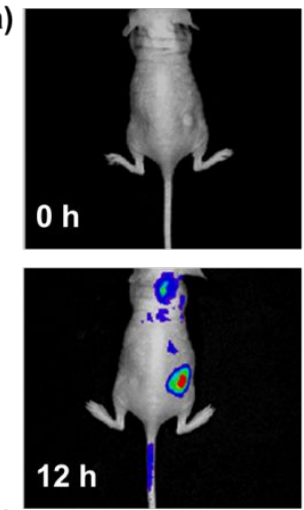

(c)
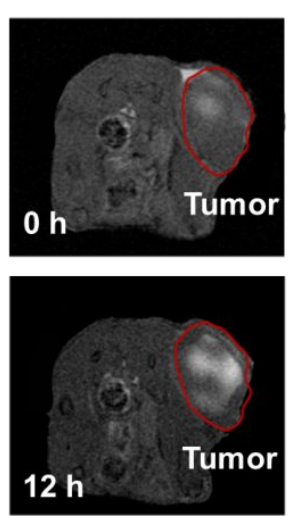
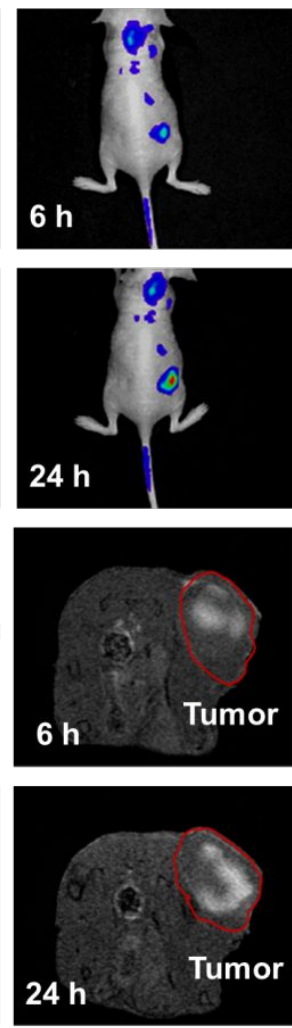

(b)

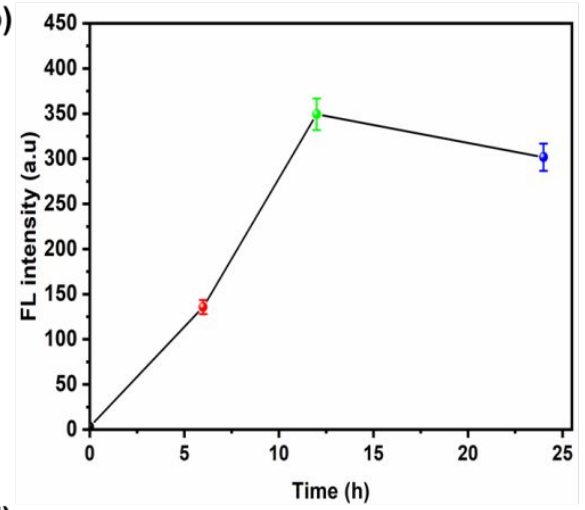

(d)
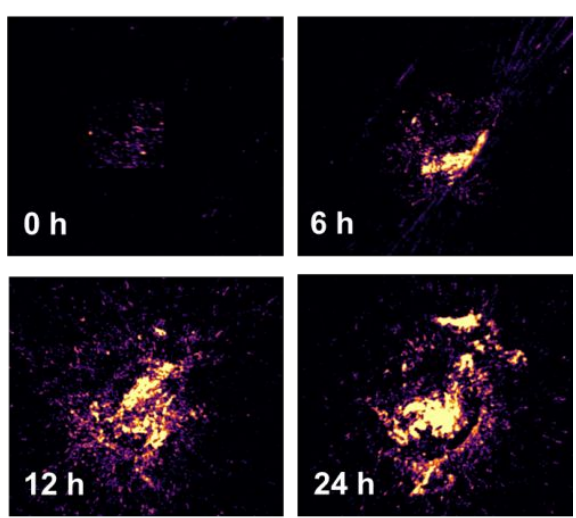

Figure 5. (a) In vivo fluorescence images of Hela tumor-bearing mice intravenously administered Cy5.5@NCs at 0-24 h post-injection. (b) Fluorescence intensity located at tumor site at 0-24 h post-injection. (c) In vivo $T_{1}$-weighted 
MRI in Hela tumor-bearing mice before and after tail veins of $\mathrm{Au} @ \mathrm{~PB} @ \mathrm{Cu}_{2} \mathrm{O} @ \mathrm{BPQDs} / \mathrm{PAH}$ NCs. (d) PA images of Hela tumor-bearing mice in vivo before and after the tail veins of $\mathrm{Au} @ \mathrm{~PB} @ \mathrm{Cu}_{2} \mathrm{O} @ \mathrm{BPQDs} / \mathrm{PAH} \mathrm{NCs}$.

As displayed in Figure 6c, the Au@PB@ $@ \mathrm{Cu}_{2} \mathrm{O} @ \mathrm{BPQDs} / \mathrm{PAH}$ NCs injected hela-bearing tumor mice indicated showed an prominent degradation on the fourth day after irradiation with $650 \mathrm{~nm}$ laser light $\left(1.5 \mathrm{~W} / \mathrm{cm}^{2}\right)$ for 5 min each day, and the tumor was almost ablated after 14 days treatment. In contrast, PBS treated hela-bearing tumor (control group), exhibited rapid growth of tumor, while group of $\mathrm{Au} @ \mathrm{~PB} @ \mathrm{Cu}_{2} \mathrm{O} @ \mathrm{BPQDs} / \mathrm{PAH} \mathrm{NCs}$ with $650 \mathrm{~nm}$ laser light $\left(0.5 \mathrm{~W} / \mathrm{cm}^{2}\right)$ illumination displayed a slow growth trend. The body weight of hela-bearing tumor mice was kept at a stable level during the treatment, demonstrating that our NCs has good biocompatibility and almost negligible toxic effect (Figure 6d). In Figure 6e, the tumors were excised after 14 days treatment, and the associated tumor weight are provided in Figure S18. The hematoxylin and eosin (H\&E) staining was used to detect the apoptosis and shape of the cancer cells. It can be seen clearly that the cells from the control group was mainly intact, while the cancer cells began to be damaged in group of $\mathrm{Au} @ \mathrm{~PB} @ \mathrm{Cu}_{2} \mathrm{O} @ \mathrm{BPQDs} / \mathrm{PAH} \mathrm{NCs}$ with $650 \mathrm{~nm}$ light $\left(0.5 \mathrm{~W} / \mathrm{cm}^{2}\right)$ irradiation and largely destructed in $\mathrm{Au} @ \mathrm{~PB} @ \mathrm{Cu}_{2} \mathrm{O} @ \mathrm{BPQDs} / \mathrm{PAH} \mathrm{NCs}$ with $650 \mathrm{~nm}$ light $\left(1.5 \mathrm{~W} / \mathrm{cm}^{2}\right)$ irradiation (Figure 6e, bottom). Besides, as shown in Figure S19, images of organs slices stemming from different treatment groups after H\&E staining indicated that the antitumor agents caused ignorable toxic effects and no remarkable histopathological abnormalities to mice. Based on these preliminary results, the $\mathrm{Au} @ \mathrm{~PB} @ \mathrm{Cu}_{2} \mathrm{O} @ \mathrm{BPQD} / \mathrm{PAH} \mathrm{NCs}$ hold great potential as PAI, $T_{1^{-}}$ weighted MRI guided PTT/PDT anticancer agents for future clinical applications.

The complete blood count assessment are discussed to further reveal any potential toxicology of $\mathrm{Au} @ \mathrm{~PB} @ \mathrm{Cu}_{2} \mathrm{O} @ \mathrm{BPQD} / \mathrm{PAH}$ NCs. To our best knowledge, liver function, and kidney function markers including alanine aminotransferase (ALT), aspartate aminotransferase (AST), blood urea level (BUN), creatinine were measured. ${ }^{54,55}$ As shown in Figure S20, all above test results are in normal reference value range in the blood of the $\mathrm{Au} @ \mathrm{~PB} @ \mathrm{Cu}_{2} \mathrm{O} @ \mathrm{BPQDs} / \mathrm{PAH}$ NCs injected mice, suggesting that no obvious toxicity or kidney disorder is induced by $\mathrm{Au} @ \mathrm{~PB} @ \mathrm{Cu}_{2} \mathrm{O} @ \mathrm{BPQDs} / \mathrm{PAH} \mathrm{NCs}$. 
(a)
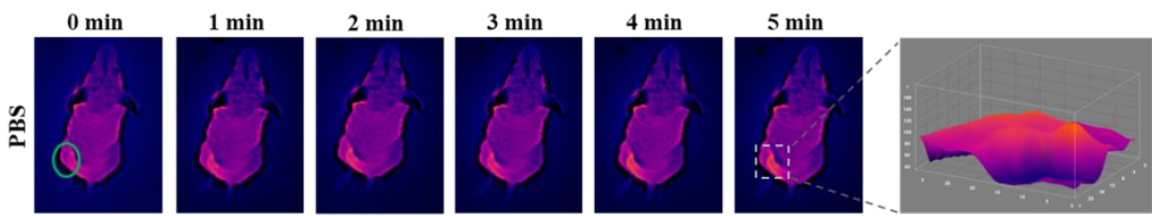

$60^{\circ} \mathrm{C}$
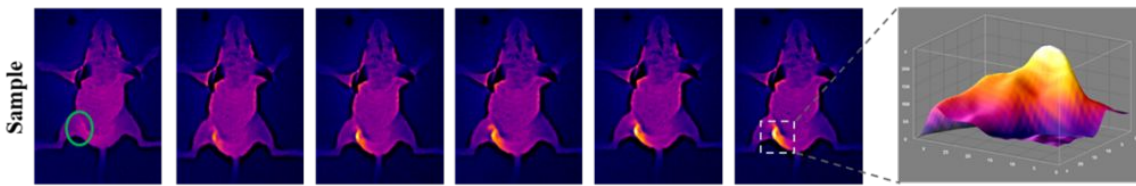

(c)
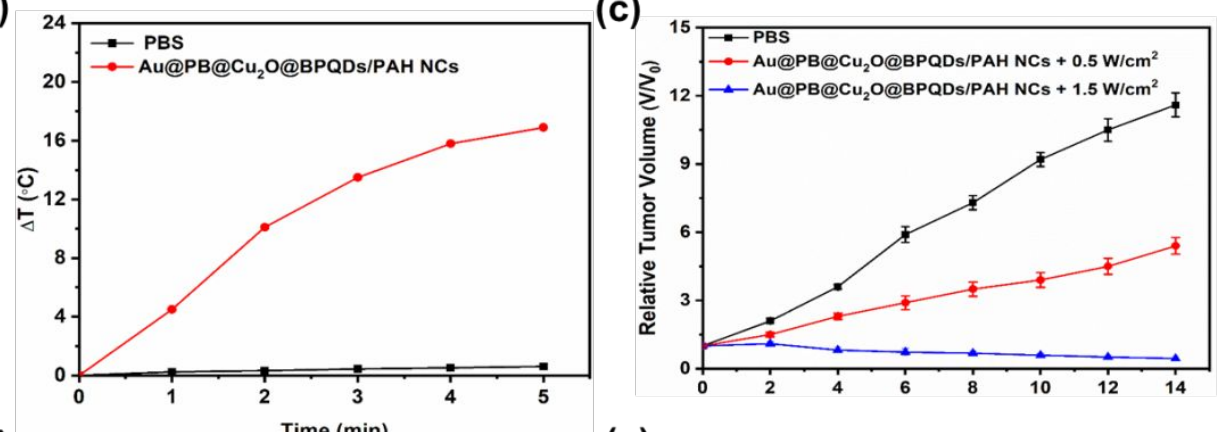

(d)

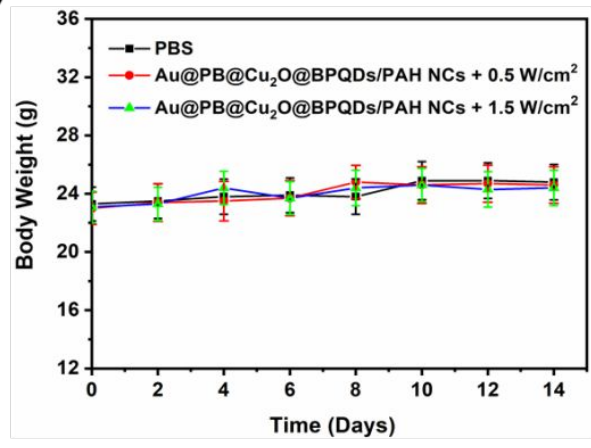

(e)

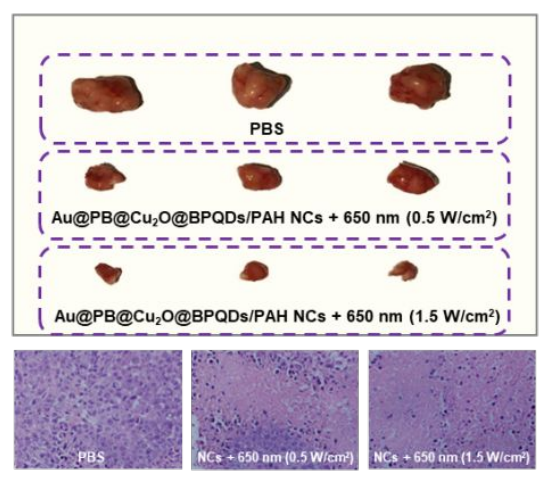

Figure 6. (a) Thermal imaging of Hela tumor-bearing mice treated with PBS (top) and $\mathrm{Au} @ \mathrm{~PB} @ \mathrm{Cu} 2 \mathrm{O} @ \mathrm{BPQDs} / \mathrm{PAH}$ NCs (bottom) before and after tail veins under $650 \mathrm{~nm}$ laser irradiation $\left(1.5 \mathrm{~W} / \mathrm{cm}^{2}, 5 \mathrm{~min}\right)$. (b) Temperature change curves at tumor sites. (c) Changes of tumor volume and (d) body weight of the mice treated with various groups after therapy (e) Photographs of excised tumors on day 14 (top) and H\&E-stained images of the tumors from different groups (bottom).

\section{Conclusions}

In summary, we have successfully fabricated $\mathrm{Au} @ \mathrm{~PB} @ \mathrm{Cu}_{2} \mathrm{O} @ \mathrm{BPQD} / \mathrm{PAH}$ NCs, a multifunctional therapeutic nanoplatform with multilayer core-shell structures for enhanced synergistic phototherapy. By introducing PB as a modified layer and BPQDs/PAH into $\mathrm{Au} @ \mathrm{Cu}_{2} \mathrm{O}$ NPs, we sufficiently utilized the mechanism of PIRET and catalase-like property of PB to achieve an dual enhanced photodynamic performance, which generated more ${ }^{1} \mathrm{O}_{2}$ (from photosensitizer $\mathrm{Cu}_{2} \mathrm{O}$ shell and BPQDs). The as-prepared NCs also exhibited great absorption in NIR region, and 
its photothermal conversion was as high as $25.73 \%$ upon $650 \mathrm{~nm}$ laser light irradiation $\left(1.5 \mathrm{~W} / \mathrm{cm}^{2}\right)$. Attributed to PB the NCs achieved a visualized synergistic therapy with the aid of MRI and PA imaging. Comparing to the $\mathrm{Au} @ \mathrm{Cu}_{2} \mathrm{O}$ NPs, our $\mathrm{Au} @ \mathrm{~PB} @ \mathrm{Cu}_{2} \mathrm{O} @ \mathrm{BPQDs} / \mathrm{PAH}$ NCs exhibited drastic improvement in bioimaging functionality and phototherapy efficiency, which offers a way to design of PIRET based nanosystems. The NCs also possessed excellent biocompatibility and photostability, which have favorable development prospect for nanomedical therapeutic applications.

\section{Supporting Information}

The Supporting Information is available free of charge on the ACS Publications. Detailed description of experimental methods and Figures S1-S16 (PDF)

\section{Author Information}

\section{Corresponding Author}

*E-mail: suyi@dtu.dk

*E-mail: mzhan@dtu.dk

\section{Acknowledgements}

This project was supported by the Villum Fonden, Denmark, Project No. 13153. T. Zheng. and M. Zhang. would like to thank the China Scholarship Council (CSC) for its generous support. We would like to thank Dr. Hongyu Sun for helping with the TEM images.

\section{Conflicts of interest}

The authors have no existing conflicts to declare.

\section{Reference}

(1) Dolmans, D. E. J. G. J.; Fukumura, D.; Jain, R. K. Photodynamic Therapy for Cancer. Nat. Rev. Cancer 2003, 3, 380-387.

(2) Ge, J.; Lan, M.; Zhou, B.; Liu, W.; Guo, L.; Wang, H.; Jia, Q.; Niu, G.; Huang, X.; Zhou, H.; Meng, X.; Wang, P.; Lee, C. S.; Zhang, W.; Han, X. A Graphene Quantum Dot Photodynamic Therapy Agent with High Singlet Oxygen Generation. Nat. Commun. 2014, 5, 1-8.

(3) Lal, S.; Clare, S. E.; Halas, N. J. Nanoshell-Enable Photothwemal Therapy : Impending Clinical Impact. 
Acc. Chem. Res. 2008, 41, 1842-1851.

(4) Wan, Z.; Mao, H.; Guo, M.; Li, Y.; Zhu, A.; Yang, H.; He, H.; Shen, J.; Zhou, L.; Jiang, Z.; Ge, C.; Chen, X.; Yang, X.; Liu, G.; Chen, H. Highly Efficient Hierarchical Micelles Integrating Photothermal Therapy and Singlet Oxygen-Synergized Chemotherapy for Cancer Eradication. Theranostics 2014, 4, 399411.

(5) Liu, Y.; Bhattarai, P.; Dai, Z.; Chen, X. Photothermal Therapy and Photoacoustic Imaging: Via Nanotheranostics in Fighting Cancer. Chem. Soc. Rev. 2019, 48, 2053-2108.

(6) Ramasamy, T.; Ruttala, H. B.; Sundaramoorthy, P.; Poudel, B. K.; Youn, Y. S.; Ku, S. K.; Choi, H. G.; Yong, C. S.; Kim, J. O. Multimodal Selenium Nanoshell-Capped Au@mSiO2 Nanoplatform for NIRResponsive Chemo-Photothermal Therapy against Metastatic Breast Cancer. NPG Asia Mater 2018, 10, 197-216.

(7) Nam, J.; Won, N.; Jin, H.; Chung, H.; Kim, S. PH-Induced Aggregation of Gold NPs for Photothermal Cancer Therapy - Supporting Information. J. Am. Chem. Soc. 2009, 131, 13639-13645.

(8) Zhou, B.; Zhao, J.; Qiao, Y.; Wei, Q.; He, J.; Li, W.; Zhong, D.; Ma, F.; Li, Y.; Zhou, M. Simultaneous Multimodal Imaging and Photothermal Therapy via Renal-Clearable Manganese-Doped Copper Sulfide Nanodots. Appl. Mater. Today 2018, 13, 285-297.

(9) Zhao, Y.; Tong, L.; Li, Z.; Yang, N.; Fu, H.; Wu, L.; Cui, H.; Zhou, W.; Wang, J.; Wang, H.; Chu, P. K.; Yu, X. F. Stable and Multifunctional Dye-Modified Black Phosphorus Nanosheets for Near-Infrared Imaging-Guided Photothermal Therapy. Chem. Mater. 2017, 29, 7131-7139.

(10) Liu, T.; Liu, Z. 2D MoS2 Nanostructures for Biomedical Applications. Adv. Healthc. Mater. 2018, 7, $1-18$.

(11) Ji, X.; Kong, N.; Wang, J.; Li, W.; Xiao, Y.; Gan, S. T.; Zhang, Y.; Li, Y.; Song, X.; Xiong, Q.; Shi, S.; Li, Z.; Tao, W.; Zhang, H.; Mei, L.; Shi, J. A Novel Top-Down Synthesis of Ultrathin 2D Boron Nanosheets for Multimodal Imaging-Guided Cancer Therapy. Adv. Mater. 2018, 30, 1-11.

(12) Li, X.; Lee, S.; Yoon, J. Supramolecular Photosensitizers Rejuvenate Photodynamic Therapy. Chem. Soc. Rev. 2018, 47, 1174-1188.

(13) BROWN, S. B.; BROWN, E. A.; WALKER, I. Review of Photodynamic Therapy in Cancer Treatment Photodynamic Therapy. The Lancet Oncol 2004, 5, 497-508.

(14) Luo, S.; Zhang, E.; Su, Y.; Cheng, T.; Shi, C. A Review of NIR Dyes in Cancer Targeting and Imaging. Biomaterials 2011, 32, 7127-7138.

(15) Yang, D.; Yang, G.; Sun, Q.; Gai, S.; He, F.; Dai, Y.; Zhong, C.; Yang, P. Carbon-Dot-Decorated TiO2 Nanotubes toward Photodynamic Therapy Based on Water-Splitting Mechanism. Adv. Healthc. Mater. 2018, 7, 1-11.

(16) Sivakumar, P.; Lee, M.; Kim, Y. S.; Shim, M. S. Photo-Triggered Antibacterial and Anticancer Activities of Zinc Oxide NPs. J. Mater. Chem. B 2018, 6, 4852-4871.

(17) Liu, C.; Dong, H.; Wu, N.; Cao, Y.; Zhang, X. Plasmonic Resonance Energy Transfer Enhanced Photodynamic Therapy with Au@SiO2@Cu2O/Perfluorohexane Nanocomposites. ACS Appl. Mater. Interfaces 2018, 10, 6991-7002. 
(18) Peng, Y.; Liu, Y.; Lu, X.; Wang, S.; Chen, M.; Huang, W.; Wu, Z.; Lu, G.; Nie, L. Ag-Hybridized Plasmonic Au-Triangular Nanoplates: Highly Sensitive Photoacoustic/Raman Evaluation and Improved Antibacterial/Photothermal Combination Therapy. J. Mater. Chem. B 2018, 6, 2813-2820.

(19) Li, C. Y.; Meng, M.; Huang, S. C.; Li, L.; Huang, S. R.; Chen, S.; Meng, L. Y.; Panneerselvam, R.; Zhang, S. J.; Ren, B.; Yang, Z. L.; Li, J. F.; Tian, Z. Q. "Smart" Ag Nanostructures for Plasmon-Enhanced Spectroscopies. J. Am. Chem. Soc. 2015, 137, 13784-13787.

(20) Cushing, S. K.; Wu, N. Progress and Perspectives of Plasmon-Enhanced Solar Energy Conversion. $J$. Phys. Chem. Lett. 2016, 7, 666-675.

(21) Li, J.; Cushing, S. K.; Meng, F.; Senty, T. R.; Bristow, A. D.; Wu, N. Plasmon-Induced Resonance Energy Transfer for Solar Energy Conversion. Nat. Photonics 2015, 9, 601-607.

(22) Li, J.; Cushing, S. K.; Bright, J.; Meng, F.; Senty, T. R.; Zheng, P.; Bristow, A. D.; Wu, N. Ag@Cu2O Core-Shell NPs as Visible-Light Plasmonic Photocatalysts. ACS Catal. 2013, 3, 47-51.

(23) Chang, Y.; Cheng, Y.; Feng, Y.; Jian, H.; Wang, L.; Ma, X.; Li, X.; Zhang, H. Resonance Energy Transfer-Promoted Photothermal and Photodynamic Performance of Gold-Copper Sulfide Yolk-Shell NPs for Chemophototherapy of Cancer. Nano Lett. 2018, 18, 886-897.

(24) Woźniak-Budych, M. J.; Przysiecka, Ł.; Maciejewska, B. M.; Wieczorek, D.; Staszak, K.; Jarek, M.; Jesionowski, T.; Jurga, S. Facile Synthesis of Sulfobetaine-Stabilized Cu2O NPs and Their Biomedical Potential. ACS Biomater. Sci. Eng. 2017, 3, 3183-3194.

(25) Hu, M.; Furukawa, S.; Ohtani, R.; Sukegawa, H.; Nemoto, Y.; Reboul, J.; Kitagawa, S.; Yamauchi, Y. Synthesis of Prussian Blue NPs with a Hollow Interior by Controlled Chemical Etching. Angew. Chemie. Int. Ed. 2012, 51, 984-988.

(26) Cheng, L.; Gong, H.; Zhu, W.; Liu, J.; Wang, X.; Liu, G.; Liu, Z. PEGylated Prussian Blue Nanocubes as a Theranostic Agent for Simultaneous Cancer Imaging and Photothermal Therapy. Biomaterials 2014, $35,9844-9852$.

(27) Yang, Z. L.; Tian, W.; Wang, Q.; Zhao, Y.; Zhang, Y. L.; Tian, Y.; Tang, Y. X.; Wang, S. J.; Liu, Y.; Ni, Q. Q.; Lu, G. M.; Teng, Z. G.; Zhang, L. J. Oxygen-Evolving Mesoporous Organosilica Coated Prussian Blue Nanoplatform for Highly Efficient Photodynamic Therapy of Tumors. Adv. Sci. 2018, 5, 1-10.

(28) Jing, L.; Liang, X.; Deng, Z.; Feng, S.; Li, X.; Huang, M.; Li, C.; Dai, Z. Prussian Blue Coated Gold NPs for Simultaneous Photoacoustic/CT Bimodal Imaging and Photothermal Ablation of Cancer. Biomaterials 2014, 35, 5814-5821.

(29) Wang, D.; Shi, R.; Zhou, J.; Shi, S.; Wu, H.; Xu, P.; Wang, H.; Xia, G.; Barnhart, T. E.; Cai, W.; Guo, Z.; Chen, Q. Photo-Enhanced Singlet Oxygen Generation of Prussian Blue-Based Nanocatalyst for Augmented Photodynamic Therapy. iScience 2018, 9, 14-26.

(30) Wang, Y.; Pang, X.; Wang, J.; Cheng, Y.; Song, Y.; Sun, Q.; You, Q.; Tan, F.; Li, J.; Li, N. Magnetically-Targeted and near Infrared Fluorescence/Magnetic Resonance/Photoacoustic ImagingGuided Combinational Anti-Tumor Phototherapy Based on Polydopamine-Capped Magnetic Prussian Blue NPs. J. Mater. Chem. B 2018, 6, 2460-2473.

(31) Yang, F.; Hu, S.; Zhang, Y.; Cai, X.; Huang, Y.; Wang, F.; Wen, S.; Teng, G.; Gu, N. A Hydrogen Peroxide-Responsive $\mathrm{O} 2$ Nanogenerator for Ultrasound and Magnetic-Resonance Dual Modality Imaging. Adv. Mater. 2012, 24, 5205-5211. 
(32) Zhang, X.; Xie, H.; Liu, Z.; Tan, C.; Luo, Z.; Li, H.; Lin, J.; Sun, L.; Chen, W.; Xu, Z.; Xie, L.; Huang, W.; Zhang, H. Black Phosphorus Quantum Dots. Angew. Chemie. Int. Ed. 2015, 54, 3653-3657.

(33) Xu, Y.; Wang, Z.; Guo, Z.; Huang, H.; Xiao, Q.; Zhang, H.; Yu, X. F. Solvothermal Synthesis and Ultrafast Photonics of Black Phosphorus Quantum Dots. Adv. Opt. Mater. 2016, 4, 1223-1229.

(34) Sun, C.; Wen, L.; Zeng, J.; Wang, Y.; Sun, Q.; Deng, L.; Zhao, C.; Li, Z. One-Pot Solventless Preparation of PEGylated Black Phosphorus NPs for Photoacoustic Imaging and Photothermal Therapy of Cancer. Biomaterials 2016, 91, 81-89.

(35) Li, Y.; Liu, Z.; Hou, Y.; Yang, G.; Fei, X.; Zhao, H.; Guo, Y.; Su, C.; Wang, Z.; Zhong, H.; Zhuang, Z.; Guo, Z. Multifunctional Nanoplatform Based on Black Phosphorus Quantum Dots for Bioimaging and Photodynamic/Photothermal Synergistic Cancer Therapy. ACS Appl. Mater. Interfaces 2017, 9, 2509825106.

(36) Mo, J.; Xie, Q.; Wei, W.; Zhao, J. Revealing the Immune Perturbation of Black Phosphorus Nanomaterials to Macrophages by Understanding the Protein Corona. Nat. Commun. 2018, 9, 1-11.

(37) Schipper, M. L.; Iyer, G.; Koh, A. L.; Cheng, Z.; Ebenstein, Y.; Aharoni, A.; Keren, S.; Bentolila, L. A.; Li, J.; Rao, J.; Chen, X.; Banin, U.; Wu, A. M.; Sinclair, R.; Weiss, S.; Gambhir, S. S. Particle Size, Surface Coating, and PEGylation Influence the Biodistribution of Quantum Dots in Living Mice. Small 2009, 5, 126-134.

(38) An, L.; Wang, X.; Rui, X.; Lin, J.; Yang, H.; Tian, Q.; Tao, C.; Yang, S. The In Situ Sulfidation of $\mathrm{Cu} 2 \mathrm{O}$ by Endogenous H $2 \mathrm{~S}$ for Colon Cancer Theranostics. Angew. Chemie. Int. Ed. 2018, 57 (48), 1578215786.

(39) Xu, Y.; Chen, D.; Jiao, X.; Xue, K. Nanosized Cu2O/PEG400 Composite Hollow Spheres with Mesoporous Shells. J. Phys. Chem. C 2007, 111, 16284-16289.

(40) Rong, K.; Zhang, H.; Wang, Q.; Huang, L.; Dong, S.; Chen, J.; Zhang, H. Prussian Blue with Intrinsic Heme-like Structure as Peroxidase Mimic. Nano Res. 2018, 11, 4905-4913.

(41) Noh, M. S.; Lee, S.; Kang, H.; Yang, J. K.; Lee, H.; Hwang, D.; Lee, J. W.; Jeong, S.; Jang, Y.; Jun, B. H.; Jeong, D. H.; Kim, S. K.; Lee, Y. S.; Cho, M. H. Target-Specific near-IR Induced Drug Release and Photothermal Therapy with Accumulated Au/Ag Hollow Nanoshells on Pulmonary Cancer Cell Membranes. Biomaterials 2015, 45, 81-92.

(42) Yu, Q.; Han, Y.; Wang, X.; Qin, C.; Zhai, D.; Yi, Z.; Chang, J.; Xiao, Y.; Wu, C. Copper Silicate Hollow Microspheres-Incorporated Scaffolds for Chemo-Photothermal Therapy of Melanoma and Tissue Healing. ACS Nano 2018, 12, 2695-2707.

(43) Yang, J.; Shen, D.; Zhou, L.; Li, W.; Li, X.; Yao, C.; Wang, R.; El-Toni, A. M.; Zhang, F.; Zhao, D. Spatially Confined Fabrication of Core-Shell Gold Nanocages@Mesoporous Silica for near-Infrared Controlled Photothermal Drug Release. Chem. Mater. 2013, 25 (15), 3030-3037.

(44) Cushing, S. K.; Li, J.; Meng, F.; Senty, T. R.; Suri, S.; Zhi, M.; Li, M.; Bristow, A. D.; Wu, N. Photocatalytic Activity Enhanced by Plasmonic Resonant Energy Transfer from Metal to Semiconductor. J. Am. Chem. Soc. 2012, 134, 15033-15041.

(45) Shi, X.; Ji, Y.; Hou, S.; Liu, W.; Zhang, H.; Wen, T.; Yan, J.; Song, M.; Hu, Z.; Wu, X. Plasmon Enhancement Effect in Au Gold Nanorods@Cu2O Core-Shell Nanostructures and Their Use in Probing Defect States. Langmuir 2015, 31, 1537-1546. 
(46) Zhang, M.; Wang, W.; Wu, F.; Graveran, K.; Zhang, J.; Wu, C. Black Phosphorus Quantum Dots Gated, Carbon-Coated Fe 3 O 4 Nanocapsules (BPQDs@ss-FeO4@C) with Low Premature Release Could Enable Imaging-Guided Cancer Combination Therapy. Chem. A Eur. J. 2018, 24, 12890-12901.

(47) Wang, X.; Ma, Y.; Sheng, X.; Wang, Y.; Xu, H. Ultrathin Polypyrrole Nanosheets via Space-Confined Synthesis for Efficient Photothermal Therapy in the Second Near-Infrared Window. Nano Lett. 2018, 18, 2217-2225.

(48) Zhang, M.; Wang, W.; Wu, F.; Yuan, P.; Chi, C.; Zhou, N. Magnetic and Fluorescent Carbon Nanotubes for Dual Modal Imaging and Photothermal and Chemo-Therapy of Cancer Cells in Living Mice. Carbon 2017, 123, 70-83.

(49) Zhang, S.; Guo, W.; Wei, J.; Li, C.; Liang, X. J.; Yin, M. Terrylenediimide-Based Intrinsic Theranostic Nanomedicines with High Photothermal Conversion Efficiency for Photoacoustic Imaging-Guided Cancer Therapy. ACS Nano 2017, 11, 3797-3805.

(50) Hessel, C. M.; P. Pattani, V.; Rasch, M.; Panthani, M. G.; Koo, B.; Tunnell, J. W.; Korgel, B. A. Copper Selenide Nanocrystals for Photothermal Therapy. Nano Lett. 2011, 11, 2560-2566.

(51) Rao, J.; Mei, L.; Liu, J.; Tang, X.; Yin, S.; Xia, C.; Wei, J.; Wan, D.; Wang, X.; Wang, Y.; Li, M.; Zhang, Z.; He, Q. Size-Adjustable Micelles Co -Loaded with a Chemotherapeutic Agent and an Autophagy Inhibitor for Enhancing Cancer Treatment via Increased Tumor Retention. Acta Biomater. 2019, 89, 300312.

(52) Lemaster, J. E.; Wang, Z.; Hariri, A.; Chen, F.; Hu, Z.; Huang, Y.; Barback, C. V.; Cochran, R.; Gianneschi, N. C.; Jokerst, J. V. Gadolinium Doping Enhances the Photoacoustic Signal of Synthetic Melanin NPs: A Dual Modality Contrast Agent for Stem Cell Imaging. Chem. Mater. 2019, 31, 251-259.

(53) Cai, X.; Gao, W.; Zhang, L.; Ma, M.; Liu, T.; Du, W.; Zheng, Y.; Chen, H.; Shi, J. Enabling Prussian Blue with Tunable Localized Surface Plasmon Resonances: Simultaneously Enhanced Dual-Mode Imaging and Tumor Photothermal Therapy. ACS Nano 2016, 10, 11115-11126.

(54) Deng, K.; Hou, Z.; Deng, X.; Yang, P.; Li, C.; Lin, J., Enhanced Antitumor Efficacy by 808 nm LaserInduced Synergistic Photothermal and Photodynamic Therapy Based on a Indocyanine-Green-Attached W18O49 Nanostructure. Adv. Funct. Mater. 2015, 25 (47), 7280-7290.

(55) Wang, M.; Deng, K.; Lu, W.; Deng, X.; Li, K.; Shi, Y.; Ding, B.; Cheng, Z.; Xing, B.; Han, G.; Hou, Z.; Lin, J., Rational Design of Multifunctional Fe@gamma-Fe2O3@H-TiO2 Nanocomposites with Enhanced Magnetic and Photoconversion Effects for Wide Applications: From Photocatalysis to ImagingGuided Photothermal Cancer Therapy. Adv. Mater. 2018, 30 (13), 1706747. 


\section{Table of Contents Graphic}

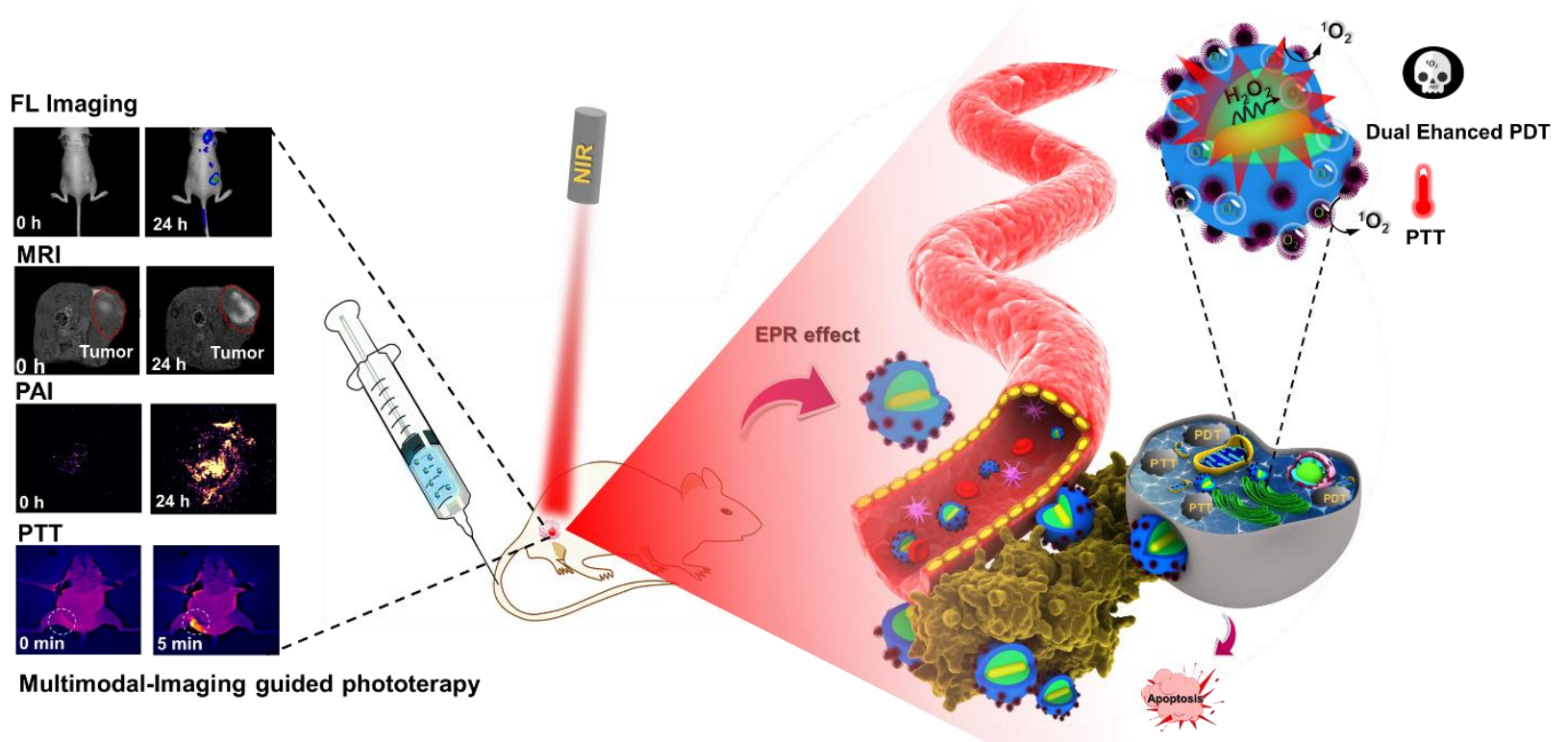

